Herger Csabáné

DOI: 10.15170/DIKE.2019.03.02.04

habilitált egyetemi docens

PTE ÁJK

\title{
A Pécsi Királyi Törvényszék ítélkezési gyakorlata a III. zsidótörvény hatályba lépését követően ${ }^{1}$
}

\section{The Practice of the Royal Court of Pécs after the "Third Jewish Law" Came into Force}

In the series of anti-Jewish measures in Hungary, the "Third Jewish Law" (August 8, 1941) was the modification of the Act XXXI of 1894 on matrimonial law. The probibition of intermarriage and the penalization of sexual intercourse between Jews and non-Jews in 1941 did not mean returning to the regulation of impediments to marriage in the confessional laws: the impediment of cultus disparitas was based on the religious affiliation of the parties, whereas the "Third Jewish Law" gave a racial definition to being Jewish. This study is the first part of publishing the results of the research in the records of the Royal Court of Pécs in private law matters in the years after the "Third Jewish Law" (1942-1945) came into force. The aim is to show the effects of the racial law in the social relations of Baranya County in South Hungary and the analyzation of the delivery of judgments when applying the disenfranchising "law".

Keywords: disfranchisement, judicial practice, marriage law, Royal Court in Pécs

\section{A kutatás tárgya és módszere}

Arra a kérdésre, hogy mit jelent egy jogász számára az igazságosság és a jogtalanság, akkor tudunk választ adni, ha alapállitásként elfogadjuk, hogy létezik igazságosság és jogtalanság, és ezek egymástól világosan elkülöníthetők. Gustav Radbruch (1878-1949) német jogfilozófus és büntetôjogász 1946-ban azt állította, hogy a bíró a pozitív jog és az igazságosság közötti konfliktus esetén akkor és csakis akkor dönthet a jogi normával szemben és ehelyett az anyagi értelemben vett igazságosság mellett, ha a kérdéses norma elviselhetetlenül igazságtalannak (,,unerträglich ungerecht") tűnik vagy a jog fogalmában alapvetően benne foglalt, minden emberre kiterjedő egyenlőség elvét tudatosan tagadja (,,bewusst verlengnet ‘). ${ }^{2}$ Radbruch tézise a törvényes jogtalanságról és a törvényfeletti jogról („,gesetzliche Unrecht und übergesetz̧liches Recht”) felhívja a figyelmet arra a lehetséges konfliktusra, mellyel a jogalkalmazó a lépcsőzetes jogkorlátozás, majd jogfosztás éveiben munkája során hazánkban is szembesült, illetve szembesülhetett.

\footnotetext{
1 A tanulmány a "Jogfosz̨ás elmélete és gyakorlata a Horthy-korszak másodike felében az NS-rendszer tükében” c. tudományos ülésen (Pécs, 2019. szeptember 2-6.) elhangzott előadás szerkesztett változata.

${ }^{2}$ Gustav Radbruch 1946-ban megjelent művének újabb kiadását lásd RADBRUCH - HASSEMER, Gesetzliches Unrecht und übergesetzliches Recht.
} 
Az Alexander von Humboldt Alapítvány által finanszírozott három éves kutatási projekt (a göttingeni Német Jogtörténeti és Polgári Jogi Tanszék valamint a pécsi Márkus Dezső Összehasonlító Jogtörténeti Kutatócsoport közötti intézményi együttmúködés) keretében e tanulmány szerzője elsősorban arra lett volna kíváncsi, hogy a III. zsidótörvény (1941. évi XV. tc.) rendelkezéseinek nyilvánvaló szembenállása a „törvény feletti” természetjoggal a pécsi bírók ítélkezési gyakorlatát befolyásolta-e, és az alkalmazandó jogot „elviselhetetlenül igasságtalannak“ látták-e. Naivitás lenne azonban azt gondolni, hogy ebben az esetben - hivatalukban megmaradva - még ítélkezhettek volna. Ezért a kutatás első tényleges kérdése az lett, hogy a pécsi bírók a bizonyítási eljárás során milyen hozzáállást tanúsítottak. Megpróbálták esetleg a törvény szigorát enyhíteni vagy a törvény betúje szerint jártak el? A kutatás során másodsorban arra kerestem választ, hogy a családjogi ügytípusok közül melyek fordultak elő, illetve mekkora volt a diszkrimináló jogi normák társadalmi jelentősége a dél-dunántúli Baranyában.

A kutatás forrása a Pécsi Királyi Törvényszéknek a Magyar Nemzeti Levéltár Baranya Megyei Levéltárában (MNL BML) fennmaradt iratanyagából az a 3.370 ügy volt, melyeket 1942-ben indítottak, függetlenül attól, hogy az eljárást melyik évben fejezték be. Ezek között nem csak magánjogi, hanem jelentős számban büntetőjogi ügyek is előfordultak, mert az arhiváláskor a különválasztás nem történt meg. A teljes 115 doboznyi iratanyag átvizsgálása azonban messze nem volt felesleges, mivel a családjog elválaszthatalan a magánjog más részeitől és a magánjogi jogfosztásnak nem egyszer büntetőjogi következménye is volt.

\section{Az ügytípusok és a jogpolitikai célzat}

A vizsgált levéltári forrásanyag magánjogi jogvitái két nagy csoportba sorolhatók. Az első csoportnál (a házasság megtámadása, illetve felbontása iránti keresetek, fajgyalázási ügyek) a III. zsidótörvény házassági jogi vonatkozású rendelkezései közvetlenül megjelentek, míg a másiknál csak a korszak egyes magánjogi intézményeinek torzulása volt felfedezhető (törvényes törvénytelen származás kérdése, örökbefogadási és öröklési szerződések).

A korszak magánjogi szakirodalma a zsidók és nem zsidók közötti házasságkötés tilalmával annyiban foglalkozott csak, hogy azt tételszerüen ismeretette, esetleg a közérdekkel indokolta, vagy az állampolgársági és származási bizonyítványok fontosságát hangsúlyozta. ${ }^{3}$ Némi visszafogott kritikát csupán az váltott ki, hogy maga a törvénycikk nem csak a zsidók jogállásával összefüggő kérdéseket szabályozott. ${ }^{4}$ Mivel ellenpéldát nem találni, megállapítható, hogy a korszak magánjogászainak nagy része - bármiféle személyes jogfelfogás kinyilvánítása nélkül - egyetértett az új normákkal, míg az esetleges kisebbség véleményét nem fejezte ki. ${ }^{5}$

A törvénycikk jogpolitikai célja a miniszteri indokolásból világosan kiderül: elsősorban a zsidó értelmiségiek viszonylag nagy száma zavarta a magyar politikai elitet. Radocsay Lász̧ó, aki 1939. november 9-től a német megszállásig több kormány alatt felelt az igazságügyi tárcáért, 1942-ben egy tanulmányában magyar jog megújításának alapvető irányai között az ún. népi gondolatot

\footnotetext{
3 ALFÖLDY - SZENTMIKLÓsI, A házassági per kézikönyve 3.

4 FEHÉRVÁRY: Magyar magánjog kistükre 141; LuSICZA, A házassági jogról szóló 1894: XXXI. törvénycikk kiegészítésérôl és módosításáról 4.

${ }^{5}$ Lásd bővebben HERGER, Az igazságosság és a jogtalanság határai a magyar magánjogban 95-97.
} 
(„,völkischer Gedanke ") is megnevezte, ${ }^{6}$ kimondatlanul is szembeállítva azt a zsidó értelmiség meghatározó szerepével. Másodsorban a vegyesházasságok folyamatosan növekvő számát nevesítették, amely - az indokolás megfogalmazójának szóhasználata szerint - „fajkeveredést” eredményez: „Magyarországon a zsidóság az egyetlen nagyobb néptömeg, amely eltérö fajként tünik fel a magyarság és az árja-fajhoz tartoró hazai nemzetiségek mellett. Annak megvilágitására, hogy mily arányban követkę̧hetik be a nem zsidók és zsidók magyarországi fajkeveredése, nem annyira a hazai 800 eqres zsidó tömeget kell szembeállitani a kb.13 milliós nem zsidó lakossággal, hanem inkább a kb. 600 ezere értelmiségi foglalkozású zsidót a kb. 4 milliónyi értelmiségi foglalkozású nem zsidóval. A zsidó fajhoz tartozók a hazai nem zsidókekal az. utóbbi félévszázad alatt egyre növekvoóbb számban házasodtak össze és ezzel mind a nem zsidók, mind a zsidók. szempontjából nemkivánatos fajkeveredés egyre nagyobb méreteket öltött. (...) A felsorolt adatok kellöképpen mutatják, hogy a nem zsidó-zsidó házasságok iránt érzett társadalmi ellenérzés, söt a zsidók társadalmi és gazdasági visszaszoritására irányuló jogszabályok sem bizonyultak elegendö visszatartó erejünek a nemkivánatos fajkeveredés megakadályozására."7

\subsection{A házasság megtámadása a Pécsi Királyi Törvényszék előtt 1942-ben folyamatba tett ügyekben}

A III. Birodalom jogalkotását követő ${ }^{8}$ III. zsidótörvény, amely a polgári házasságról szóló 1894 . évi XXXI. tc. (Ht.) módosítását és kiegészítését tartalmazta, megtiltotta a zsidók és nem zsidók közötti házasságkötést. Az izraeliták és keresztények közötti házassági akadály, amely a Ht. hatályba lépése előtti felekezeti jogokban a cultus disparitas körébe tartozott, a törvény 9. szakaszában a származáson alapuló zsidófogalommal egészült ki. Az akadály ellenére kötött vegyesházasság érvényes volt, de büntetendő (14. \$). A büntetéssel való fenyegetés nem csak a házasságkötő felekre terjedt ki, hanem az állami anyakönyvvezetőre is, aki szándékosan vagy gondatlanságból közremúködött egy ilyen házasságkötésnél. ${ }^{9}$ A vizsgált levéltári anyagban azonban egyetlen zsidó-nem zsidó vegyesházasság miatt vagy annál történt közremúködés miatt indított büntetőper sem volt. Ez különösen annak fényében érdekes, hogy a fajvédelmi házassági köteléki jogi szabályok Magyarországon ugyan a vegyesházasságok számanak drasztikus csökkenéséhez, de nem megszűnéséhez vezettek: míg 1895 és 1918 között ez a szám folyamatosan emelkedett, a két háború közötti időszakban stagnált, a II. világháború éveiben csupán erôsen visszaesett. ${ }^{10}$ Karády Viktor házassági anyakönyvek alapján összeállított adatközlése szerint 1941-ben a törvény hatályba lépésétől (1941. november 1.) Budapesten az év utolsó két hónapjában az éves átlaghoz (90) képest 4,7 \% volt a vegyesházasságok aránya, 1942-ben az éves átlahoz képest (98) 6,5%. Számításainál Karády értelemszerủen nem a

\footnotetext{
${ }^{6}$ RADOCSAY, Die Rechtserneuerung in Ungarn 2.

7 https:// net.jogtar.hu/ezer-ev-torveny?docid=94100015.TVI\&searchUrl=/ezer-ev-orvenyei\%3Fpagenum\%3D51.

${ }^{8}$ Gesetz zum Schutze des deutschen Blutes und der deutschen Ehre vom 15. September 1935; Gesetz zum Schutz der Erbgesundheit des deutschen Volkes vom 18. Oktober 1935; Gesetz zur Vereinheitlichung des Rechts der Eheschließung und der Ehescheidung im Lande Österreich und im übrigen Reichsgebiet vom 6. Juli 1938.

${ }^{9}$ „Az a magyar honos nem zsidó, aki zsidóval, az a zsidó, aki magyar honos nem zsidóval, úgyszintén az a magyar honos zsidó férfi, aki külföldi honos nem zsidó növel a 9. $\int$-ban foglalt tilalmat megszegve házasságot köt, büntettet követ el és öt évig terjedhetö börtönnel, bivatalvesztéssel és politikai jogai gyakorlatánake felfüggesztésével büntetendö. Ugyanígy büntetendő az a polgári tisztviselö, aki tudja, hogy a 9. S-ban foglalt házassági akadály áll fenn és a házasság megkötésénél közremüködik. Ha pedig a polgári tisztviselö gondatlanságból müködik közre az ilyen házasság megkötésénél, vétséget követ el és büntetése három hónapig terjedhetö fogháa."

${ }^{10}$ KARÁDY, Asszimiláció és társadalmi krízis 145.
} 
felekezeti hovatartozást, hanem a származáson alapuló zsidó-definíciót vette figyelembe. ${ }^{11}$ Bár pécsi adatok nem állnak rendelkezésre, vélelmezhető, hogy ha elvétve is, de Pécsett is előfordultak vegyesházasságok.

A büntetőperek hiánya ezek esetében minden bizonnyal azzal magyarázható, hogy belügyminiszteri engedély ${ }^{12}$ birtokában kötötték meg ôket. Karády kiemelte, hogy az érintettek közül sem a férfiaknál, sem a nőknél nem voltak elhanyagolható számúak Budapesten az ilyen házasságok, sôt éppen a végveszély hónapjaiban, az NS-megszállást (1944. március 19.) követően, jelentősen meg is szaporodtak. Felhívta a figyelmet arra is, hogy abban a rövid időszakban, amikor a III. zsidótörvény már hatályba lépett, de a zsidó vallás recepciójának megszüntetése, azaz a zsidóságba való betérés jogi lehetőségének felszámolása még nem történt meg, Budapesten 1941-ben 224, 1942-ben 255 keresztény nő judaizált. A betért hölgyek töredékéről, mintegy 20 \%-áról jegyezték csak fel, hogy visszatérő volt, míg a Karády által ismert adatok szerint férfiak esetében, ha történt is betérés ebben a korban, az többnyire ténylegesen csak visszatérést jelentett. Bár keresztény nők 1941 előtt is a férfiaknál nagyobb számban judaizáltak, Karády az 1941-es és 1942-es adatokat történelmileg teljesen egyedülálló betérési hullámnak nevezte, és hangsúlyozta, hogy ez nem csak Budapesten, hanem más asszimilációs központokban is előfordult. Magyarázatot erre a jelenségre csak az érzelmekben talált: az elmulasztott vegyesházassági tervek megvalósítása vagy a meglévő érzelmi-szexuális közösség tovább megőrzésének vágya vezethette a sorsközösséget vállaló nôket akkor, ${ }^{13}$ amikor a házasságon kívüli kapcsolatot fajgyalázásként büntetéssel fenyegette a jogalkotó.

A belügyminiszteri engedéllyel kötött vegyesházasságok körét nem tekintve a zsidó-nem zsidó vegyesházasság megkötésének magánjogi jogkövetkezménye megtévesztésre hivatkozva a házasság megtámadásának lehetősége volt (10. §). A Ht. a házasság érvénytelenségének két formáját ismerte: a semmisséget és a megtámadhatóságot. ${ }^{14}$ A III. zsidótörvény megtartotta a házasság megtámadásának Ht-ben felsorolt okait (1. a házasságkötő felek elégtelen életkora, 2. kiskorú házasságkötő fél törvényes képviselője beleegyezésének a hiánya, 3, kényszer, tévedés, megtévesztés), csak némileg kiegészítette azokat: megtámadható volt a házasság, „ha a megtévesztés olyan ténykörülményre vonatkozik, amely a házastárs személyi állapotának megitélése szempontjából a 9. J értelmében lényeges, s a megtévesztést a másik házastárs tudva maga idézte eló, vagy tudta a megtévesztést, amely egy harmadiktól ered" (10. §). Az, hogy a zsidó vagy nem zsidó származás a lényeges személyes tulajdonság fogalmi körébe vonható-e, a II. zsidótörvény óta (1939. évi IV. tc.) vitatott volt. A III. zsidótörvény hatályba lépését követően a bírói joggyakorlat válasza erre a kérdésre kétséget kizáróan igenlő volt. ${ }^{15}$

A törvény rendelkezett a jegyesek házasságkötés előtti kötelező orvosi vizsgálatáról (1-4. 『S), valamint a házassági kölcsön intézményéről is, amit az Országos Nép- és Családvédelmi Alapból a házasságkötés alkalmával a bizonyítottan egészséges igénylőknek utaltak ki. Ha a törvény miniszteri indokolásában nevesített eugenikai és fajvédelmi célzatról nem tudnánk, még azt is mondhatnánk, hogy a kötelező orvosi vizsgálat a prostitúció hiányos és nem kellően hatékony szabályozása, valamint a nemi betegségek gyakori előfordulása miatt ${ }^{16}$ hasznosnak túnhetett a maga

\footnotetext{
${ }^{11}$ KARÁDY, A vegyesházasságok Budapesten 1950 előtt 84.

${ }^{12}$ A feltételekről és az engedélyezési eljárásról lásd STEIN, A zsidók érvényes házasságának alaki kellékei.

${ }^{13}$ KARÁDY, A vegyesházasságok Budapesten 1950 előtt 85-86.

${ }^{14}$ Lásd bővebben HERGER, A nővételtől az állami anyakönyvvezetőig 102-103.

15 ALFÖLDY - SZENTMIKLÓSI, A házassági per kézikönyve 104.

${ }^{16}$ CSÁszÁR: A kéjelgésügy szabályozása 15-28.
} 
korában, mint ahogy a házassági kölcsönt is tekinthetnénk a házasság intézményét támogató eszköznek. A szabályozási környezet és a köztörténeti háttér azonban kizárja, hogy a kötelező orvosi vizsgálatnak és a házassági kölcsön intézményének ilyen értelmet adjunk. A 6. \ szerint az új megtámadási okok közé bekerült az az eset is, „ha házastársa az 1. $\int$ alá esö betegségre vonatkozóan a megtévesztést tudva maga idézte eló akár elótte, akár a tiszti orvos vagy a vizsgálatot teljesitố orvos elött lényeges ténykörülménynek. hamis állitásával vagy elhallgatásával, vagy pedig tudta a megtévesżtést, amely egy harmadiktól ered. Végezetül a házasság megtámadható volt "tévedés miatt akekor is, ha az egyik házasfél már a bázasságkötéskor gyógyithatatlan elmebetegségben szenvedett és a másik házasfél ez̨t nem tudta s a körülményekböl sem követkętethette” (7. §). A házastárs elmebetegsége azonban nem volt megtámadási ok akkor, ha a megbetegedés a házasság fennállása alatt következett be.

A vizsgált levéltári anyagban megtámadási ügyek csak kivételesen fordultak elő. Az 1942ben a Pécsi Királyi Törvényszék előtt folyamatba tett öt megtámadási per alapján a köveztkező négy állítás fogalmazható meg: 1. A keresetben az azt benyújtó házastárs a házasság érvénytelenné nyilvánítása mellett minden esetben másodlagosan a házasság felbontását is kérte, amit valószínúleg a megtámadási okok bizonyításának nehézségeivel magyarázhatunk. A Ht. hatályba lépését követő években a Pécsi Királyi Törvényszék előtt nem fordult elő ilyen eset. ${ }^{17}$ Amikor azonban a kodifikálatlan, curiai praxison alapuló házassági köteléki perekben alkalmazott eljárásjogot ${ }^{18} 1915$ től felváltották az első magyar polgári eljárásjogi kódex (1911. évi I. tc.) szabályai, a két kereseti kérelem együttes érvényesítése nem volt kizárt, sőt a megtámadási és bontó perek eljárási szabályai közelebb kerültek egymáshoz: ámbár az 1911. évi I. tc. szerint az ún. előzetes békéltetés két típusa, a kereset benyújtása előtti (645. \) illetve a kereset benyújtása utáni (654. \) békéltetés csak ágytól és asztaltól történő elválasztásra és bontásra irányuló kereset esetén volt lehetséges, ${ }^{19}$ a per során lefolytatott békéltetést (668. §) kiterjesztették a megtámadási perekre is. Ha tehát a kereset alkalmas volt arra, hogy idézést bocsássanak ki, a bíróság határidőt tűzött a bíróság előtti békéltetésre a házastársak valamelyike által indított megtámadási perben is. 2. A házastársak legalább egyike az említett öt megtámadási per közül csak kettőben volt a III. zsidótörvény értelmében zsidó. Származásuknak az ügy érdeme tekintetében azonban nem volt jogi jelentősége egyik perben sem. 3. Az 1942-ben folyamatba tett perek között nem volt olyan, melyben a törvény 1. \-ban meghatározott betegség vonatkozásában szándékos megtévesztésre hivatkoztak volna. 4. A házastársnak a házasságkötés időpontjában fennálló, a másik fél gyógyíthatatlan emebetegségre vonatkozó tévedése csak egy esetben szerepelt megtámadási okként a keresetlevélben.

Varga József és V as Júlia napszámosok perének jelentősége elsősorban abban állt, hogy - az előző korszak gyakorlatával szemben - a felperes egy keresetben kérte a házasság érvénytelenítését és felbontását is. A felek 1941. június 21 -én kötöttek házasságot Pellérden. Házassági együttélésük ez év szeptember 22-ig tartott a szomszédos faluban, Görcsönyben. Az elhidegülés oka közöttük az volt, hogy a férj - a keresetlevél szerint - már a nászéjszakán megállapította, hogy felesége nem volt érintetlen a házasságkötéskor. A falubeli pletykák szerint mástól volt teherben, amit igazolni látszott, hogy a feleség nővérével rövid időre távozott a házból, majd véresen, gyengén tért haza, és hosszabb ideig beteg volt. A férj tapasztalatlanságával magyarázta, hogy a történteket ekkor még nem helyesen értelmezte. A következő hónapokban felesége háztartási kötelezettségeit nem látta el, vele szeretetlenül viselkedett, tilalma ellenére a szomszéd pusztára járt egy idegen férfihoz, majd szeptember 22-én elhagyta. Távozása előtt a nő

\footnotetext{
${ }^{17}$ Lásd bővebben HERGER, A nővételtől az állami anyakönyvvezetőig 173.

${ }^{18}$ HERGER, A házassági kötelék védelmét szolgáló eszközök 71-94.

${ }^{19}$ FABINYI: A polgári perrendtartás 104-107.
} 
bevallotta korábbi kapcsolatát, sőt terhességét is, a későbbiekben pedig a fenti férfival nyilvánosság előtt is rendszeresen mutatkozott. Varga József a házasságkötéskor fennálló lényeges és súlyos tévedésre hivatkozva, illetve mivel felesége őt lényeges személyes tulajdonságára nézve szándékosan megtévesztette, a házasságot a Ht. 54. 』e, pontja és 55. 』alapján megtámadta, ha pedig a megtámadás sikerre nem vezetne, egyidejűleg felesége vétkes cselekményére hivatkozva a Ht. 80. \a és c, pontja alapján a házasság felbontását is kérte. ${ }^{20}$ A Pécsi Királyi Törvényszék felperes keresetét 1943. március 3-án elutasította. Az indokolás szerint alperes a kereset elutasítását és a házasság fenntartását kérte arra hivatkozva, hogy a velük együtt élő anyós és sógornő veszekedéséit nem tudta elviselni, de ha férje külön lakóhelyet biztosít számukra, oda örömmel követi. A bíróság a tanúvallomások alapján megállapította, hogy felperest menyasszonya „vastagságára” a házasságkötéskor saját anyja figyelmeztette. Ezek alapján sem a megtámadási ok, sem a bontó ok nem állt fenn. ${ }^{21}$ 1943. november 20-án a Pécsi Királyi Ítélőtábla az eljárás felfüggesztését rendelte el végzésében arra hivatkozva, hogy felperes jogi képviselője katonai szolgálatra vonult be.22 1944. március 28-án, tíz nappal a német megszállást követően született meg a Pécsi Királyi Ítélőtábla másodfokú ítélete a perben, mely a bizonyítékok hiányára hivatkozva az elsőfokú itéletet helybenhagyta. ${ }^{23}$

Kétyi István felesége, Zsoldos Mária ellen ugyancsak vagylagos keresetet terjesztett elő: a Ht. 54 \ 1. pontja alaján házasságuk érvénytelenné nyilvánítását kérte (mivel a nő nem engedte a házasságot elhálni, és Kétyi István a házasságkötéskor nem tudott menyasszonya betegségéről), illetve a Ht. 80. \a, pontja alapján egyben bontást is kért a nő vétkessé nyilvánítása mellett. A csatolt anyakönyvi kivonatokból megtudjuk, hogy mindkét fél római katolikus vallású volt. A per nem érdemi ítélettel fejeződött be, hanem Zsoldos Mária halála miatt az eljárást megszüntették. ${ }^{24}$

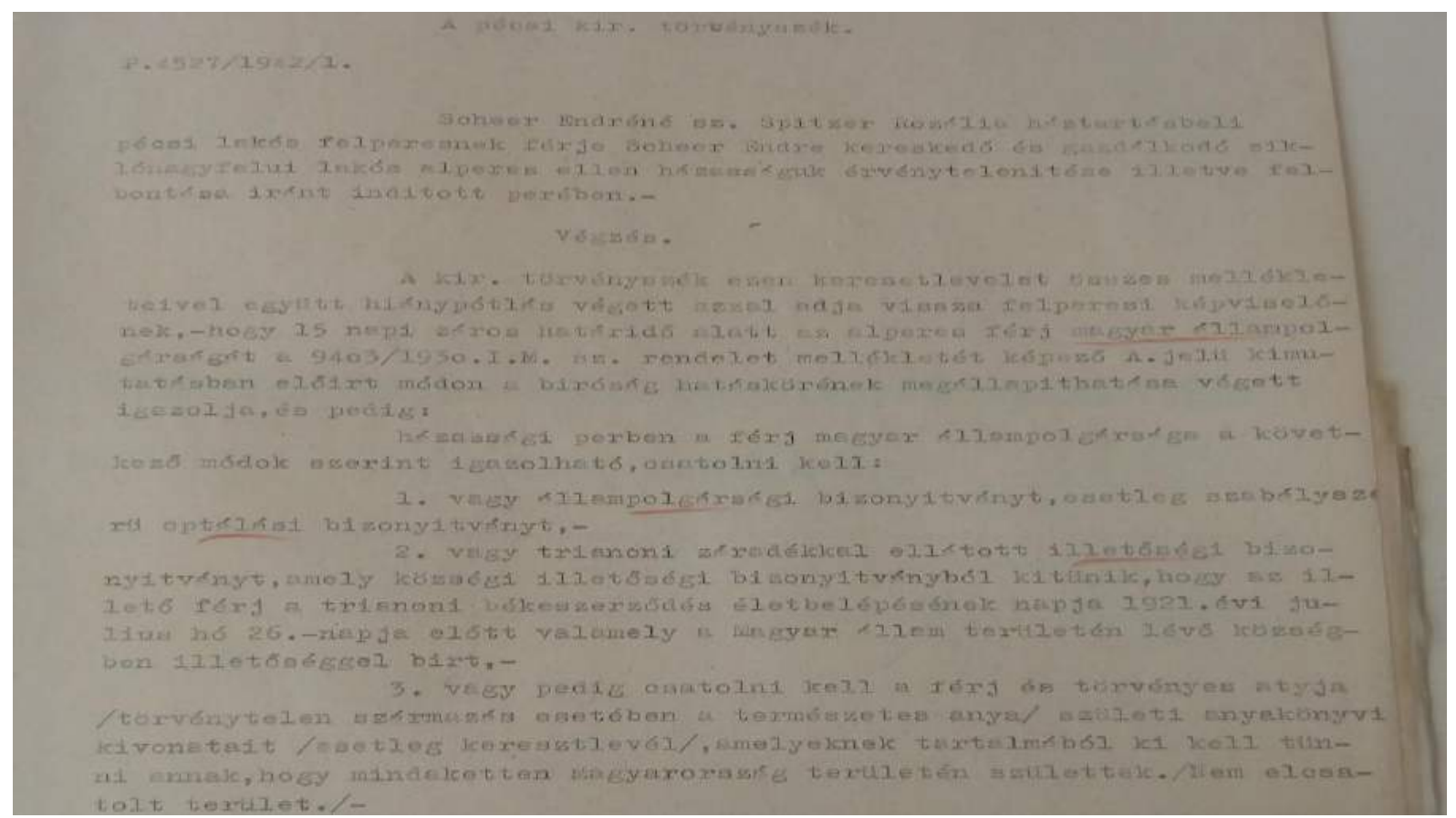

1. ábra: A Pécsi Királyi Törvényszék végzése a bíróság illetékességének megállapításához szükséges állampolgársági bizonyítvány benyújtásáról. MNL BML VII/2b II/4527/1942/1 sz. végzés.

Spitz̧er Borbala keresetlevelében ehhez hasonlóan két kérelmet fogalmazott meg: egyrészt megtámadta a siklósnagyfalui zsidó kereskedővel, Scheer Endrével kötött házasságát, másrészt a házasság felbontását is kérte. A kereset beadását követően hiánypótlásra szólította fel a Pécsi Királyi Törvényszék, a hiányzó állampolgársági bizonyítványt azonban az

${ }^{20}$ MNL BML VII/2b 680/1942 sz., szám nélküli keresetlevél, 1942. február 17.

${ }^{21}$ MNL BML VII/2b 680/1942/14. sz. ítélet.

${ }_{22}^{2}$ MNL BML VII/2b 680/1942/22. sz. végzés.

${ }^{23}$ MNL BML VII/2b 680/1942/31. sz ítélet.

${ }^{24}$ MNL BML VII/2b 2242/1942 sz. 
asszony a rendelkezésére álló tizenöt nap alatt nem nyújtotta be. Mivel Magyarország a trianoni békediktátum következtében területének kétharmadát elveszítette, ezek a bizonyítványok a peres akták többségében előfordultak, amennyiben a felek állandó lakhelyének fekvése a bíróság illetékességének megállapításához szükségesnek látszott. ${ }^{25}$

A római katolikus vallású felek, Gyurós Julianna és Dobsæai Lajos között a házastársi kapcsolat a férj epileptikus rohamai miatt romlott meg. A periratokban az érvénytelenné nyilvánítás és bontás iráni igény szintén pontatlanul, felváltva szerepelt. A jogerős ítéletben azonban a Ht. 55. 』alapján érvénytelenné nyilvánította a Pécsi Királyi Törvényszék a házasságot. ${ }^{26}$ Ehhez hasonlóan bontási és érvénytelenítési igény vagylagosan szerepelt a keresetben Marjanovics Naum dárdai tanító felesége, Hert Anna ellen indított köteléki perében. ${ }^{27}$

A tanulmány témája szempontjából egy jelentősebb megtámadási ügy volt a vizsgált levéltári anyagban. Lóke Lászৃó Tibor, az Alsódunántúli Mezőgazdasági Kamara intézője és Sżing Klára herceszöllősi lakosok 1941. január 4-én kötöttek házasságot, melyből egy gyermek született. A férj keresetlevelében előadta, hogy nagyatyja, Lőke Lajos zsidó volt, aki házasságkötése előtt római katolikus vallásra tért, azaz gyermekei születésükkor már katolikusnak lettek keresztelve. Kezdettől fogva boldogtalan házasságukat felesége idegállapotával és abnormális természetével, többszöri öngyilkossági kísérletével magyarázta. Az életközösség a felek között 1942. február 26-án szűnt meg, amikortól a férj az irodájában aludt és hétvégén is ott maradt. Mivel felesége leánykori idegösszeomlásáról a házasságkötéskor nem volt tudomása, a bíróságtól elsősorban megtévesztésre hivatkozva a házasság érvénytelenítését (Ht. 55. §) kérte, másodsorban pedig annak felbontását (Ht. 80. \a) és felesége vétkessé nyilvánítását kérte a férj, aki ekkor már főhercegi uradalmi intéző volt Hercegszőlősön. ${ }^{28} \mathrm{Az}$ aktában szerepelt a felperes állampolgársági bizonyítványa is, mely szerint a tiranoni békeszerződést becikkelyező 1921. évi XXXIII. tc. rendelkezésének megfelelően 1922. július 1-jén bejelentette állampolgársága fentartására irányuló elhatározását. ${ }^{29}$

A per a bontóperekben szokásos eljárás szerint zajlott. A sikertelen békéltetést követően tárgyalási határnapot tűztek, ${ }^{30}$ majd az alperes ellenkeresetet terjesztett elő, melyben a megtámadási és a bontási kérelem együttes tárgyalását, a per tartamára különélés elrendelését és ideiglenes nőtartást kiszabását kérte, valamint azt, hogy felperes katonai szolgálata ellenére a per felfüggesztését ne rendeljék el. Az alperesi előkészítő iratban a feleség a következőket állította: „felperes a maga iránti szimpátiát felkelteni célzó önvallomásként beismeri, hogy apai részról zisidó származáaú", (...) „de házasságkötésüket megelözóen koránt sem volt ilyen öszinte, mert zsidó származását, ami a mai idök. felfogásán keresztül igen lényeges személyi tulajdonságnak minösül, elhallgatta". Ezért ő lenne az - folytatódik az irat - aki megtévesztésre hivatkozva a házasságot megtámadhatná, de ezt ő nem teszi, mert megbocsátotta férjének „a szüleim és az én társadalmi helyzetem tekintetében is nagy súllyal jelentkező megtévesatést”. A házasságot gyermekükre való tekintettel tartotta fenn, és felperesnek a származását nem hánytorgatta a szemére akkor sem, amikor a férfi „éppen ezen származási személyi tulajdonsága folytán nem lett véglegesitve" a munkahelyén, más pályázatát elutasították, és csak a nő atyjának személyes közbejárására alkalmazták a hercegi uradalomban is. Az ő döntése volt, hogy a

\footnotetext{
25 MNL BML L VII/2b 4527/1942 sz.

${ }^{26}$ MNL BML VII/2b 3776/1942 sz.

27 MNL BML VII/2b 4291/1942 sz.

${ }^{28}$ MNL BML VII/2b 1216/1942 sz., szám nélküli keresetlevél, 1942. március 24.

${ }^{29}$ MNL BML VII/2b 1216/1942/13 sz. bizonyítvány, 1942. március 24.

${ }^{30}$ MNL BML VII/2b 1216/1942/2 sz. békéltetési jegyzőkönyv.
} 
békülésben bízva viselni kénytelen férje „sqármazása szépséghibájának következményeit”. ${ }^{11}$ Az ideiglenes nőtartást elrendelő végzést ${ }^{32}$ követően felperes tartalékos tüzérhadnagyként az orosz fronton szolgált 1942 májusától. Szabadsága alkalmával kérte a per felfüggesztésének megszüntetését, de rövid idô múlva az alperesi képviselő bevonulása miatt újra felfüggesztésre került sor. A törvényszék 1944. június 8-án 6 hónapra ágytól és asztaltól elválasztotta a feleket, ${ }^{33}$ és ennek letelte után - amennyiben a békülés nem történt meg - felperest feljogosította végleges bontás kérésére. Az 1946. május 13-i hivatalos jelentés szerint a perben a nyilvántartási idő letelt, azaz a per érdemi ítélet nélkül zárult le, ${ }^{34}$ valószínúleg felperes frontszolgálatban bekövetkező halála miatt. A per során - a kereseti kérelemmel szemben - a megtámadás kérdésével a bíróság nem foglalkozott, és a jegyzőkönyvekben illetve határozatokban is bontóperként jelölték az ügyet.

A III. zsidótörvény által nyitott kapu hatása a Pécsi Királyi Törvényszék területén, Baranya megyében 1942-ben, amikor a legnagyobb ügyforgalom volt várható, gyakorlatilag nulla volt. Ennek magyarázatát valószínűleg a társadalmi mentalitásban kell keresni. Magyarországon 1895. október 1. óta kötelező állami házasságkötés és anyakönyvvezetés volt, ezért a házastársak felekezeti hovatartozása, illetve a zsidó-nem zsidó vegyesházasságok száma nehezen kideríthető: a születési anyakönyvi kivonatok lehetnének eligazítók. Míg a Ht. hatályba lépése utáni években a házas felek vallása az ügyiratokból csak akkor derült ki, ha a házasságot még a felekezeti jogok hatálya alatt kötötték, vagy - kivételesen - az eltérő felekezeti hovatartozás volt a házassági konfliktus oka, a vizsgált levéltári forrásanyaban már minden ügynél csatolták a születési, illetve házassági anyakönyvi kivonatokat, amelyek igazolták a felek vallását és származását, a III. zsidótörvényhez igazodva.

A házasság megtámadása az 1895 utáni évtizedekben is rendkívül ritkán került sor Baranyában, ${ }^{35}$ ezért ez a trend nem meglepő. Valószínú az is, hogy a zsidó származás és vallás nem olyan személyes tulajdonság volt a háború elôtti évtizedekben, melyre nézve a felek megtévesztették volna a jegyesüket. Ez sokkal inkább akkor történt, ha a nő a házasságkötéskor mástól már teherben volt, ahogy a fenti jogesetek egyike is jó példa erre. Fontos végül azt is megjegyezni, hogy ha a házasság véglegesen megromlott, a vétkességi elven alapuló, de liberális magyar bontójog kínált megoldást a házasságból való kilépésre. Ezért nem volt szükség arra, hogy a felek a házasság megtámadásának eszközével éljenek.

\subsection{Bontóperek a Pécsi Királyi Törvényszék előtt 1942-ben folyamatba tett ügyek között}

A háborús évek házassági bontójoga továbbra is a Ht. szabályain nyugodott. A klasszikus liberalizmus értékei iránt elkötelezett szabadelvű kormány 1894-ben - a püspöki kar és a katolikus főrendek ellenállása ellenére - a kötelező polgári házasságkötést, egységes bontójogot és egységes állami jurisdictiót bevezető (nem konzervatív, de nem is szabadelvű, hanem sokkal inkább

\footnotetext{
${ }^{31}$ MNL BML VII/2b 216/1942 sz., dátum és szám nélküli alperesi előkészítő irat.

32 MNL BML II/2b 1216/1942/4. sz. végzés, 1942. június 16.

${ }^{33}$ MNL BML VII/2b 1216/1942/38. sz. ítélet.

${ }^{34}$ MNL BML VII/2b 1216/1942/44. sz. hivatalos jelentés.

${ }^{35}$ HerGER, A nôvételtől az állami anyakönyvvezetőig 173.
} 
visszafogottnak mondható) házassági törvény megalkotásáról döntött. ${ }^{36} \mathrm{~A} \mathrm{Ht}$. bontójoga a vétkességi elven nyugodott, elutasítva az objektív bontó okokat és a közös megegyezésen alapuló bontást is. Abszolút bontó ok bizonyítása esetén a bíróság minden további nélkül bontotta fel a házasságot, míg relatív bontó ok bizonyítása esetén a bontáshoz a feldúltság megvalósulására is szükség volt. ${ }^{37}$

\begin{tabular}{|c|c|c|c|}
\hline \multirow{4}{*}{ abszolút bontóok } & 76. 5 & házasságtörés, fajtalanság, bigámia & \multirow[t]{4}{*}{ vétkességi elv } \\
\hline & 77. $\int \mathrm{a}-\mathrm{b}$ & szándékos és jogos ok nélküli elhagyás & \\
\hline & 78. 5 & $\begin{array}{l}\text { a házastárs életére törés vagy a házastárs szándékos és } \\
\text { súlyos bántalmazása }\end{array}$ & \\
\hline & 79.5 & $\begin{array}{l}\text { a házastársat halálra vagy legalább } \text { öt év } \\
\text { szabadságvesztésre ítélték a házasságkötést } \\
\text { megövetően } \\
\text { megvósított bűncselekmény miatt }\end{array}$ & \\
\hline \multirow{4}{*}{ relatív bontóok } & 80. $\int \mathrm{a}$ & $\begin{array}{l}\text { a házastársi kötelezettségek szándékos és súlyos } \\
\text { megsértése }\end{array}$ & \multirow{4}{*}{$\begin{array}{l}\text { feldúltsági } \\
\text { elvvel vegyített } \\
\text { vétkességi elv }\end{array}$} \\
\hline & 80. $\int \mathrm{b}$ & $\begin{array}{l}\text { a házastársak családjához tartozó gyermek rábírása } \\
\text { büncselekmény elkövetésére vagy erkölcstelen életmódra, } \\
\text { illetve a rábírás megkísérlése }\end{array}$ & \\
\hline & 80. \c & erkölcstelen életmód megátalkodott folytatása & \\
\hline & 80. $\int \mathrm{d}$ & $\begin{array}{l}\text { a házasságkötést követôen elkövetett bűncselekmény } \\
\text { miatt } 5 \text { évnél rövidebb időtartamú szabadságvesztés vagy } \\
\text { nyereségvágyból elkövetett vétség elkövetése miatt } \\
\text { szabadságvesztés időhatár nélkül }\end{array}$ & \\
\hline
\end{tabular}

2. ábra: A bontóokok rendszere az 1894. évi XXXI. tc-ben (forrás: a szerző összeállítása)

A Ht. bontójogát a III. zsidótörvény egy mondattal egészítette csak ki: a bontást nem akadályozza az, ha a bontóok megvalósítását követően a vétkes házastárs elmebetegségbe esik (8. 〕). Az 1894 és 1945 közötti évek házassági köteléki jogára vonatkozó levéltári kutatások alapján megállapítható, hogy ez a mondat teljes mértékben felesleges volt. A Ht. az objektív bontóokokat, azaz az elmebetegség bontó okként történő elismerését is elutasította. Ha azonban egy szubjektív (vétkességi elven alapuló) bontóok megvalósulása bizonyítást nyert, illetve relatív bontóok esetén a feldúltságot is megállapította a bíróság, a házasságot felbontották, függetlenül attól, hogy a vétkes házastárs a bontás időpontjában elmebeteg volt vagy sem. A jogalkotó azonban talált két curiai döntvényt, melyre a módosítás indokaként hivatkozott (P. VIII. 2196/1906, P. III. 2461/1940): ezekben a bíróság a bontókeresetet - egyértelműen hibásan - azért utasította el, mert a házastárs elmebetegség miatt gondnokság alatt állt. Ezekben az esetekben a főbíróság nem vette figyelembe, hogy a bontóok a megbetegedés előtt valósult meg, ezért - állította a miniszteri indokolás szükségesnek látszik az elv megerôsítése. ${ }^{38}$ Ilyen módon a polgári jogi kultúra jogegyenlőségi elvét elvető III. zsidótörvény a köztudatba - legalábbis a bontójog tekintetében - a jogállamiság őreként igyekezett bevonulni.

1941. november 1. után a Pécsi Királyi Törvényszék bontójogi gyakorlatában újdonságot nem igazán lelhetünk fel. Az azonban szembetűnik az aktákat olvasó és a korábbi évtizedek gyakorlatát is ismerő kutatónak, hogy az ítélkezésben némi konzervatív fordulat mutatkozott. A

\footnotetext{
36 A Ht. előkészítéséhez lásd HeRGER, Tradition und Modernisierung in der Geschichte der Zivilehe in Ungarn 275282.

${ }^{37}$ WEISs, Vétkesség - feldúltság és a házasfelek közös megegyezése 909-919.

38 https:/ / net.jogtar.hu/ezer-ev-torveny?docid=94100015.TVI\&searchUrl=/ezer-ev-torvenyei\%3Fpagenum\%3D51.
} 
századforduló óta a 77. \a, pontjára (szándékos és jogos ok nélküli elhagyás) alapított bontások egyre gyakoribbá váltak: az alperes rendszerint meg sem jelent a bíróság előtt és egyáltalán nem is védekezett, nemegyszer ágyasságban élt, sôt a gyermekek születési adataiból nyilvánvaló volt, hogy ők is az ágyasságból, nem pedig a formálisan még fennálló házasságból születtek. ${ }^{39}$ A bírói praxis segítségével a vétkességi elv fellazult, és az elméletileg elutasított közös megegyezésen alapuló bontás - a szándékos és jogos ok nélküli elhagyás „eljátszásával“ - mégis megvalósulhatott. Ezzel szemben a vizsgált levéltári anyagban feltűnő, hogy a bíróság figyelembe vette azt is, ha az előzetes peren kívüli eljárás lefolytatását követően a felperes ágyasságra lépett. A korábbi évtizedekben rendszerint csak azt vizsgálták, hogy az előzetes peren kívüli eljárás idején volt-e ágyassági kapcsolata a házastársak bármelyikének, mivel az - természetesen - akadályozta a kibékülést.

Ez a gyakorlat látható a Krémer Ferenc által felesége, Krieg Erzsébet ellen folyamatba tett bontóperben is. A felek 1919. november 16-án kötöttek házasságot, melyből két, már nagykorú gyermek származott. Krieg Erzsébet 1938. február 15én elhagyta férjét, aki ezért a bíróságtól azt kérte, hogy végzésében kötelezze az asszonyt az életközösség helyreállítására. A 4033/1942 számú határozat arra is feljogosította az elhagyott házastársat, hogy ha felesége tizenöt nap alatt (azaz 1942. november 21-ig) nem tér hozzá vissza, bontókeresetet nyújtson be. Az eredménytelen peren kívüli eljárást követően a bíróság már a bontókeresetről döntött. Ámbár a nő a tárgyaláson azt vallotta, hogy a férjét már nem szereti és nem akar vele élni, a felperes férj keresetét 1944. július 13-án elutasították, mert a férj 1942 novemberében házvezetőnőként magához vett egy idegen nőt, amit a bíróság ágyasságnak tekintett. Ez a szemléletmód a Pécsi Királyi Törvényszék előtti bontóperekben teljes mértékben új volt. ${ }^{40}$

A házastársak vallásának vagy származásának a megtámadási perekhez hasonlóan a bontóperekben is csekély jelentősége volt. Abban a hét bontóperben, melyben a keresetet 1942ben terjesztették a Pécsi Királyi Törvényszék elé és a peres felek legalább egyike zsidó volt, a származásnak vagy vallásnak a perben jogi jelentősége egyáltalán nem volt. Természetesen ez nem jelenti azt, hogy a bontóok alapjául szolgáló házassági konfliktus kialakulásához a származás vagy a vallás - különösen vegyesházasság esetén - kisebb-nagyobb mértékben ne járulhatott volna hozzá.

Klein Anna és Schelcæeer Mór kovácshidai kereskedő 1928. március 1-jén kötött házasságot Pécsett. A felek mindketten izraeliták voltak. Házasságukból négy évvel később egy fiúgyermek született. A férj beszerzőútjai során felesége egyedül volt otthon. 1941 márciusában Schelczer Mórt 3 hónap munkaszolgálatra hívták be, de június 10-én váratlanul haza érkezett. Lakásukban feleségét egy idegen férfival találta. A keresetlevélben a felperes férj erről a következőképp írt: „(...) nem bittem, hogy 140 kg súlyú zsidó feleségem egy közismert nyilas kerületi vez̧etövel adja összue magát. Vesz̨ekedtem emiatt vele, sö́t arra került sor, hogy egy izben el is küldött, de visszamentem. Azóta azonban kétségtelen bizonyitékot szereztem, hogy a feleségem a szeretöje már évek óta Bethlen Ferencnek, és a nevezettet pénzeli az én keserves keresményemböl”. A férjet a nő a kizárólagos tulajdonában álló házból elzavarta, ezzel az életközösség köztük megbomlott, ezért a férj a házasság felbontását és felesége vétkessé nyilvánítását kérte a Ht. 80. \a, és c, pontja, továbbá 85. \alapján. ${ }^{41}$ A per érdemi határozat nélkül

\footnotetext{
${ }^{39}$ Mindeközben a 80. \a, pontjára (házastársi kötelezettségek súlyos és szándékos megsértése) alapított bontások száma továbbra is magas volt.

${ }^{40}$ MNL BML VII/2b 4912/1942/19 sz. ítélet.

${ }^{41}$ MNL BML VII/2b 718/1942 sz., szám és keltezés nélküli keresetlevél.
} 
ért véget, mert az 1942. december 22-én tartott szóbeli tárgyaláson a felperesi képviselő bejelentette, hogy megbízója az orosz fronton mintegy két héttel korábban, december 5 -én elesett. ${ }^{42}$

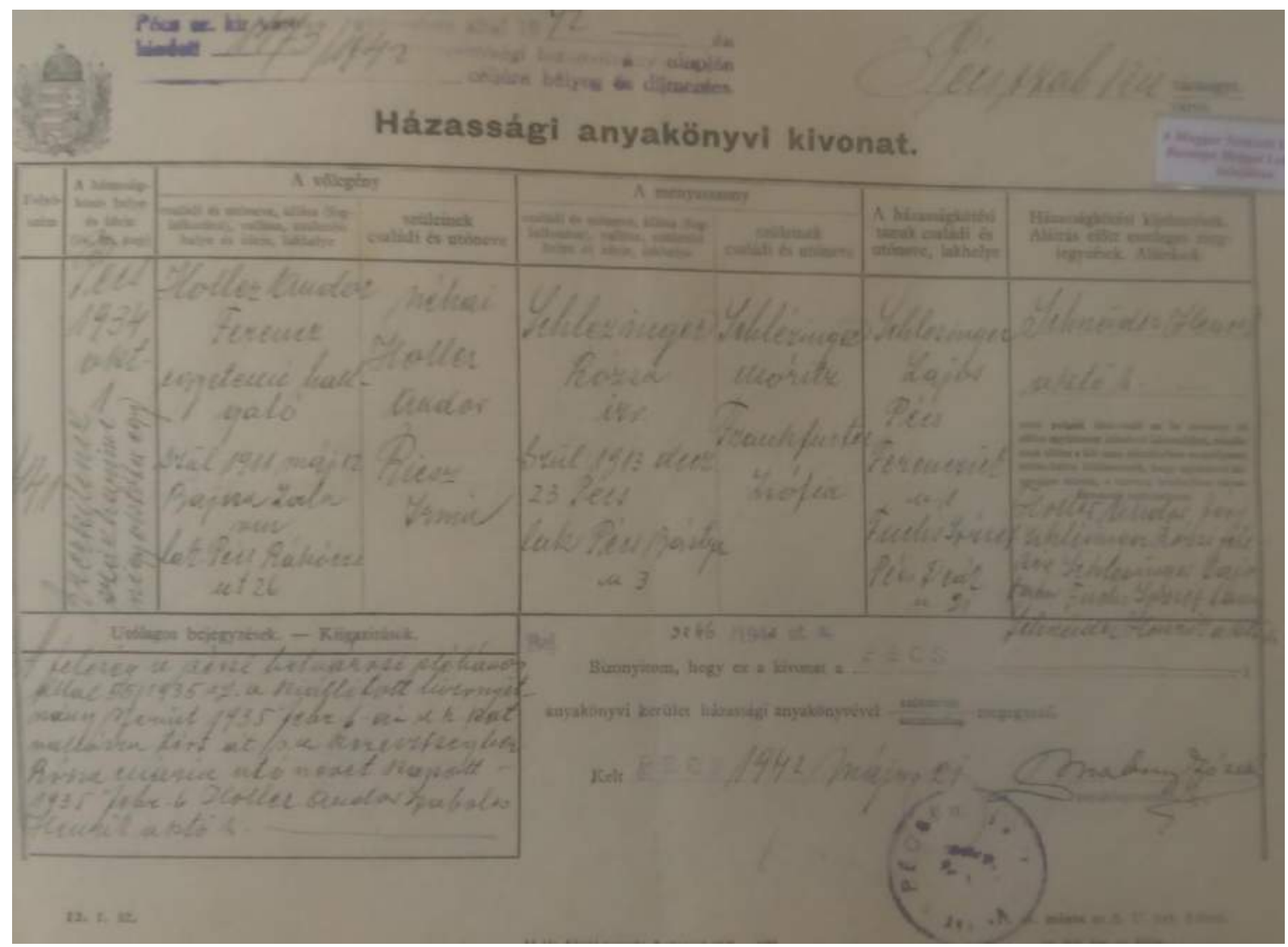

3. ábra: 1934. október 1-jei keltezésű házassági anyakönyvi kivonat, melynek utólagos bejegyzése szerint az egyetemi hallgató Holler Andor Ferenc, aki Pécsett, a Rákóczi út. 26. szám allatt lakott, 1935-február 6-án római katolikus vallásra tért, miközben felesége, Schlesinger Rózsa izraelita vallású maradt. MNL BML VII/2b 3316/1942 sz.

Brucker Sándor vasesztergályos-segéd felesége, Pinternits Ilona elleni bontókeresetét a Ht. 77. $\int$ a, pontjára alapította. A férj izraelita, a nő kitért római katolikus volt. Férjét, akit nem sokkal később munkaszolgálatra köteleztek, 1941. október 7-én hagyta el. 1942. október 24-én az eljárást a felperes távolléte miatt felfüggesztették. Az asszony a felfüggesztés figyelmen kívül hagyását azzal az indokolással kérte, hogy "férjem zsidó én pedig keresztény, de a zsidótörvény szerint én is annak számitok". ${ }^{3}$ A perben az ítélet 1943. május 20-án született meg. A Pécsi Királyi Törvényszék a feleket a Ht. 77. $\int$ a pontja alapján egymástól elválasztotta és az alperes nőt vétkesnek nyilvánította. Az indokolás szerint „az életközösséget helyreállitani nem hajlandó, mert férjétól azért jött el, mert a férjét sohasem szerette és emiatt egymással összeférni nem birtak”, azaz az életközösség megromlásában vajmi kevés szerepe volt a felek vallásának, figyelembe véve azt is, hogy származása szerint a feleség is a zsidótörvények hatálya alá tartozott. ${ }^{44}$

\footnotetext{
${ }^{42}$ MNL BML VII/2b 718/1942/15. sz. tárgyalási jegyzőkönyv.

${ }^{43}$ MNL BML VII/2b 3677/1942/2 sz. jegyzőkönyv.

${ }^{44}$ MNL BML VII/2b 3677/1942/4 számú ítélet.
} 
A zsidó származású felek köteléki pereiben jellemző, hogy a kitért fél rendszerint nevét is magyarosította, a gyermekek vallásukban a kitért szülőt követték, és a felek bontás esetén nagyobb hajlandóságot mutattak a perbeli kérdések (vagyonjogi igény, gyermekelhelyezés) egyezséggel történő rendezésére, mint ez a nem zsidó peres felek esetében jellemző volt. ${ }^{45} \mathrm{~A}$ zsidó származású vagy vallású peres felek alacsony száma, amely szembeötlő a korábbi évtizedekhez képest, valószínúleg a háborús körülményekkel, a férfiak munkaszolgálatra való kötelezésével magyarázható, ami az eljárás felfüggesztéséhez vagy a kereset visszavonásához vezetett. ${ }^{46} \mathrm{~A}$ bontókeresetek - ahogy ez nem zsidó felek esetében is legtöbbször így volt - a Ht. 80. 『-án vagy 77. S-án alapultak. ${ }^{47}$

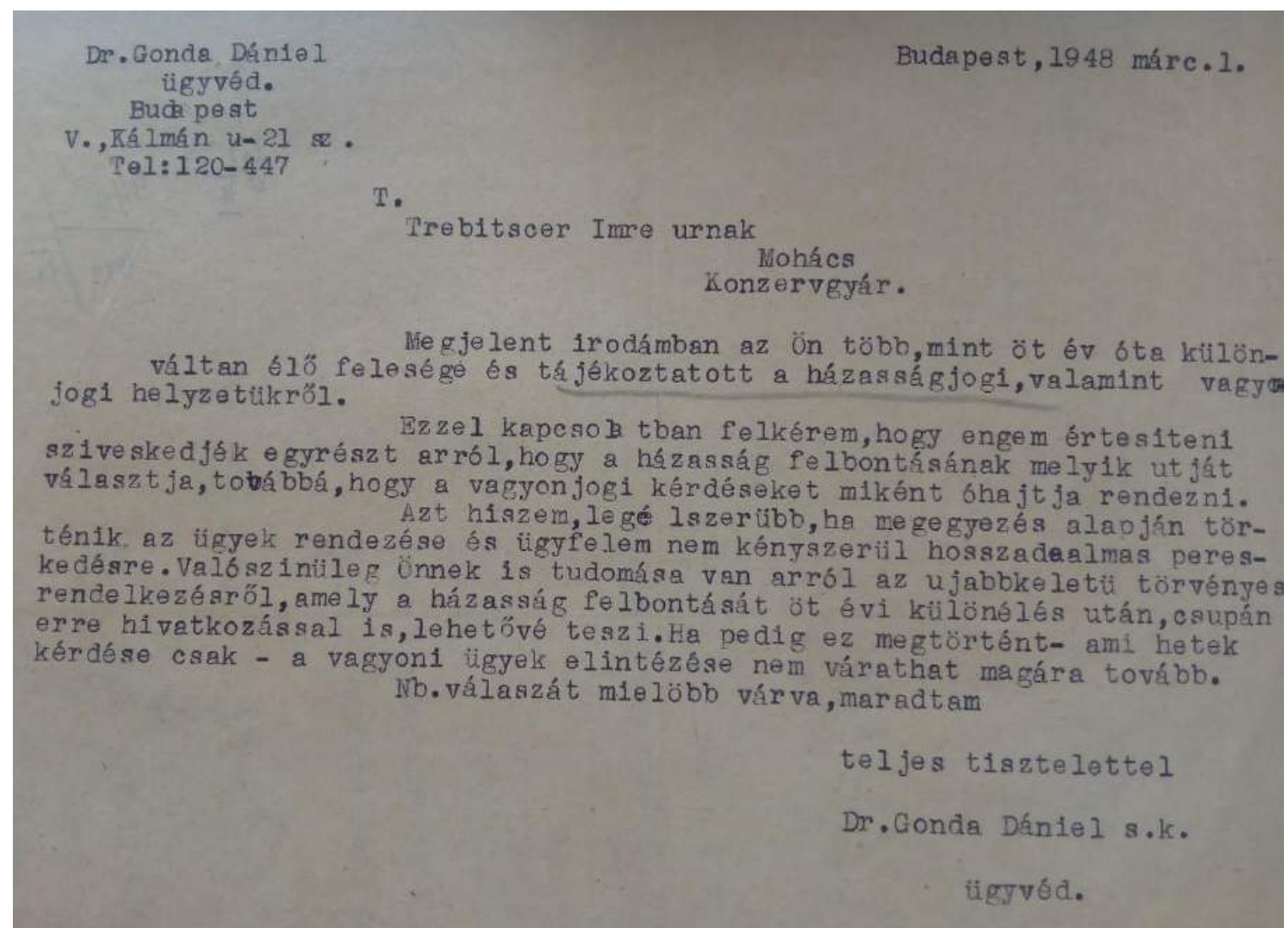

4. ábra: Gonda Dániel mohácsi ügyvéd tájékoztatása a bontójog változásairól az alpres felé az MNL BML VII/2b 4194/1942 sz. ügyben.

A háborús évek ítélkezési gyakorlatában kontinuitás mutatkozott az 1952. évi IV. tc., első családjogi törvénykönyvünk hatályba lépéséig. Lebr Livia férje, Trebicser Imre bontóperében a perindítás utáni hetedik évben, 1949-ben született csak jogerős ítélet. ${ }^{48}$ A felek mindketten zsidó származásúak, de római katolikus vallásúak voltak. A férjénél jóval fiatalabb asszony nagy hozománnyal érkezett a mohácsi ecet- és konzervgyár tulajdonosának házába. Keresetében 133.500

\footnotetext{
45 Többek között MNL BML VII/2b 3316/1942 sz.

46 MNL BML VII/2b 3010/1942 sz.

${ }^{47}$ MNL BML VII/2b 1170/1942 sz. és 1510/1942 sz.

${ }^{48}$ MNL BML VII/2b 4194/1942 sz.
} 
pengő közszerzemény megállapítására is igényt formált, ami azért érdekes, mert a hozomány (40.000 pengö) visszaköveteléséhez is joga lett volna. A felek között az életközösség 1942. július 21-én szűnt meg a nő kicsapongó életvitele és az emiatti veszekedések következtében. Az életközösséget a rokonok békítési kísérletei ellenére sem állíttták helyre, melynek elsősorban vagyonjogi ellentétek, másodsorban a férj „női becsületet sértő” megjegyzése („,k...”) volt az oka. 1942. szeptember 22-én a feleség a közös lakásból véglegesen távozott. A bíróság a nő házasságtörését - az alperesi tanúk vallomása és a bemutatott fényképek ellenére - nem találta hitelt érdemlôen bizonyítottnak, míg a 80. \a, pontjában foglalt relatív bontó okot fennforogni találta, és ezért a házasságot 1948. szeptember 29-én mindkét fél vétkessé nyilvánítása mellett felbontotta, illetve a felperesi bontókeresetet a Pp. 672. \ (felperes nem jelent meg a tárgyaláson) alapján elutasította és a felperesi vagyonjogi igény elbírálását külön perbe utalta. ${ }^{49}$

Az eset különösen azért érdekes, mert a 6800/1945 számú miniszterelnöki rendelet lehetôvé tette a felek közös megegyezésén alapuló bontást, illetve egy további, objektív bontóokot is bevezetett: ha a házastársak öt éve külön éltek, a bíróság nem vizsgálta más bontóok megvalósulását. Trebicser Imre és felesége, akik a népirtást mindketten túlélték, ezt a lehetőséget azonban az ügyvédi figyelmeztetés ellenére sem használták ki. Azt már csak találgathatjuk, hogy döntésükben mekkora jelentősége volt a kommunikációs hajlandóság teljes hiányának vagy annak az elvárásnak, hogy a bíróság a vétkesség kérdésében is döntést hozzon.

\subsection{Fajgyalázási perek a Pécsi Királyi Törvényszék előtt 1942-ben folymatba tett ügyek között}

Mivel a III. zsidótörvény fajgyalázási tényállása (15. () a házasságon kívüli nemi kapcsolatokra vonatkozott, világos, hogy ez képezte az összekötő elemet a törvény heterogén szabályai és a fajvédelmi célzat között. A törvény miniszteri indokolása és a korszak magánjogi szakirodalma is a szükésges fajvédelem részeként tekintett a házassági jog ilyen módon történő kiegészítésére, illetve módosítására annak érdekében, hogy „a zsidó sžellem uralmát” Magyarországon felszámolják. ${ }^{50} \mathrm{~A}$ házasságon kívüli nem kapcsolat büntetéssel történő fenyegetése zsidók és nem zsidók között csak a férfi elkövető ellen irányult, és kizárólag az ún. tisztességes nőt védelmezte. A vizsgált levéltári forrásanyagban kevés, mindössze öt olyan fajgyalázási per anyaga található, melyekben a vádemelés 1942-ben történt. A vétség vádjával indított eljárásokat két esetben megszüntették, három ügyben pedig felmentő ítélet született.

Az 1942. július 10-i keltezésű 1123/1942. sz. jegyzőkönyv szerint a 17 éves, négy elemi iskolai osztályt végzett, izraelita vallású és pécsi születésû Breuer György árukihordóként heti 25 pengőt keresett. Ismerőse meglátogatásakor Pécsett, a Lánc utca 25. szám alatti házban találkozott azzal a házas nővel, aki egy pengő ellenében magát felkínálta neki. Ezért állítása szerint joggal hihette azt, hogy kéjnővel áll szemben. Bock Ferencné (a csatolt iratokban a nő nevének írása változó volt) egyébként nemi betegséggel is megfertőzte a fiatal férfit, aki ezért feljelentést tett ellene. ${ }^{51}$

\footnotetext{
${ }^{49}$ MNL BML VII/2b 4194/1942/34. sz. ítélet, 1948. szeptember 29.

${ }^{50}$ LUSICZA: A házassági jogról szóló 1894: XXXI. törvénycikk kiegészítéséről és módosításáról 4.

${ }^{51}$ MNL BML VII/2b 2764/1942 sz., fejlelentés, 1942. április 10.
} 


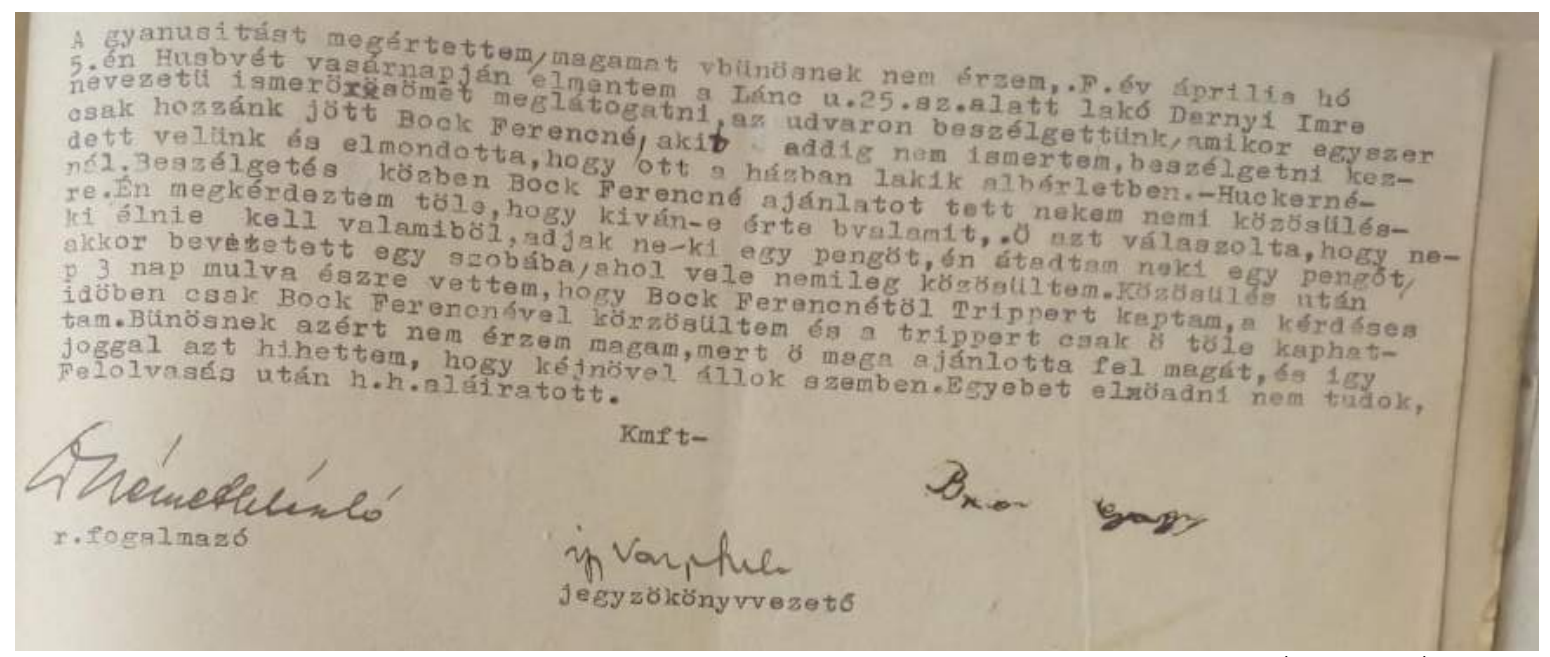

5. ábra: Az 1942. július 10-i keltezésű 1123/1942. sz. jegyzőkönyv 3. oldala. MNL BML VII/2b 2764/1942

A bírósági akta tartalmazta a M. kir. Rendőrség pécsi kapitányságának detektív testülete által kiállított jelenést is, mely szerint 1942. április 5-én a fiatalkorú Breuer György „Bak Mária keresz̨ény

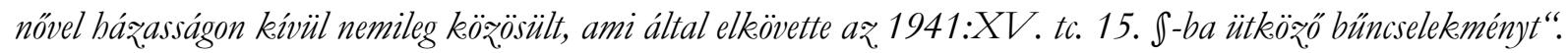
Az iratot $V$ arga Imre detektív és Kamarás, a detektív testület vezetője írta alá. ${ }^{52}$ Pár nappal késóbb a testület újabb jelentést készített. Eszerint a „Bakk. Ferencné szül. Prigl Mária 34 éves osżteferi szüll. rk. férjes, mindenes (...) elöadta, hogy megfelel a valóságnak” a fenti állítás. A jelentés szerint Breuer György szintén úgy nyilatkozott, hogy „megfelel a valóságnak, hogy fhó 5 -én hivta Bake. Ferencnét, hogy vele nemileg közösüijön. Bakk Ferencné a kérésének eleget is tett (...). Tagadja (azonban), hogy ezenkivül más keresztény növel házasságon kivül nemileg közösült. Végül tisz̧telettel jelentem, hogy Bakk. Ferencné mint mindenes keresi kenyerét és nem folytat kereseti viszonyait meghaladó életmódot. A kérédéses közösülést megelözóen érintetlen nem volt. Hogy férjén kivül más férfival is élt volna nemi életet, a nyomzás során megállapitani nem sikerült. A közööülésért 1 pengöt kapott. Nevezett itt kéjnöként bejegyezve nincs és nem is volt. ${ }^{\text {"53 }}$ A csatolt erkölcsi bizonyítványból kiderül, hogy a gyanúsítottnak főfoglalkozása nem volt, katonai szolgálatot nem teljesített, hosszúkás arcú, barna hajú, barna szemú férfi volt, aki a bűnügyi nyilvántartásban nem szerepelt, míg a vagyoni bizonyítvány szerint állami adó fizetésére előírása nem volt. ${ }^{54} \mathrm{Az}$ ügyben a Pécsi Királyi Törvényszék 1942. december 31-én hozott végzést: a Breuer György ellen fajgyalázás vétsége miatt indított bűnvádi eljárást megszüntették, mert „a tárgyaláson a királyi ügyész a vádat indokoltan elejtette és a vád képviseletére jogsult sértett nincsen". A végzésen, melyet Varga József tanácselnök, a fiatalkorúak bírája írt alá, a jogerőről szóló záradék is szerepelt. ${ }^{55}$

\footnotetext{
52 MNL BML VII/2b 2764/1942 sz., jelentés, 1942. április 11.

${ }^{53}$ MNL BML VII/2b 2764/1942/1123 sz. jelentés, 1942. április 20.

${ }^{54}$ MNL BML VII/2b 2764/1942 sz., erkölcsi illetve vagyoni bizonyítvány, 1942. október 30.

${ }^{55}$ MNL BML VII/2b 2764/1942/5. sz. végzés, 1942. december 31.
} 


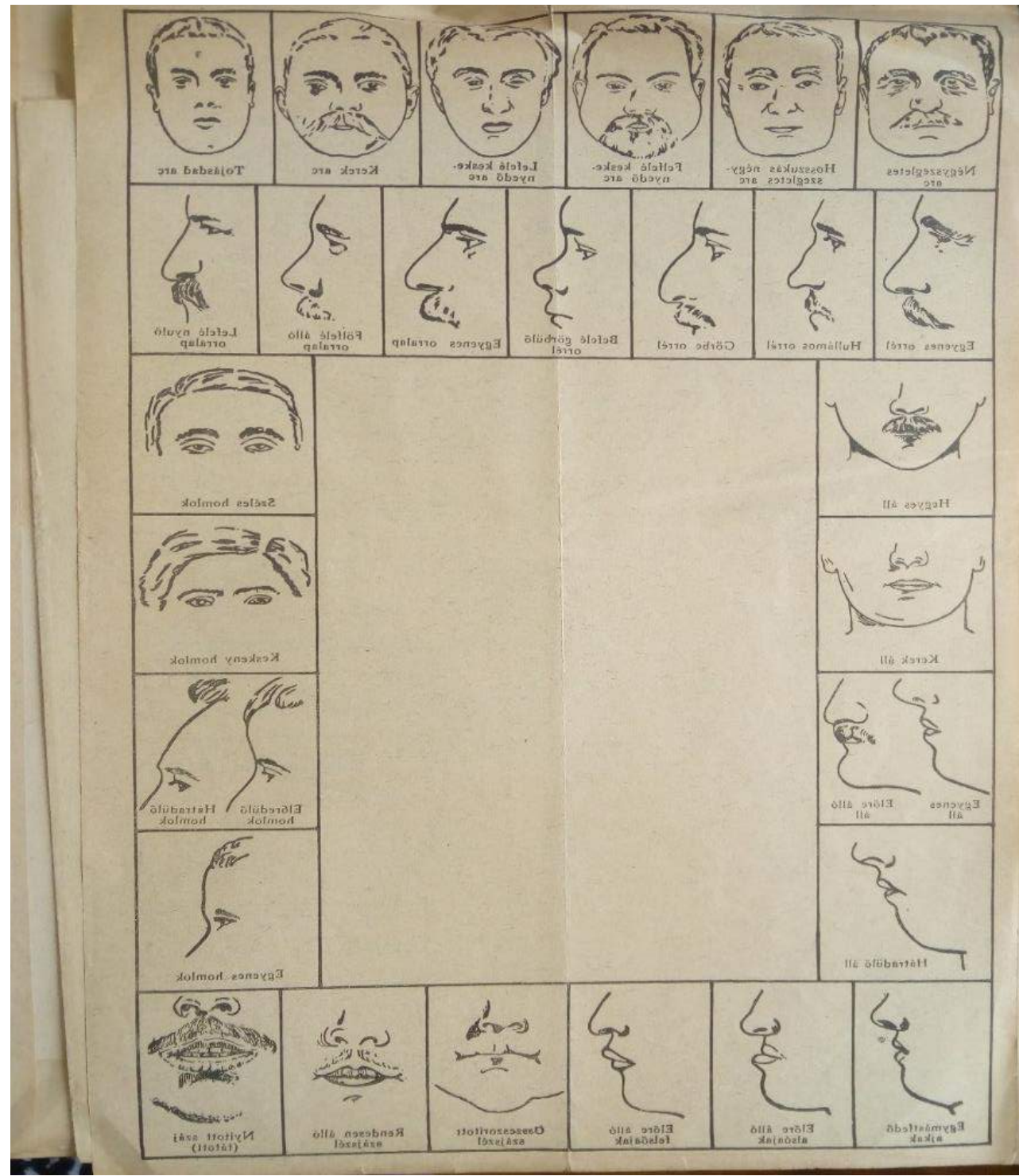

6. ábra: Az 1942. április 10-én készített személyleírás 2. oldala. MNL BML VII/2b 2764/1942

A Glatter Mór gyanúsított elleni eljárás alapja a M. Kir. Pécsi IV. Csendőrkerület jelentése szerint a szentlőrini járás főszolgabírájához intézett névtelen feljelentő levél, valamint a főszolgabíró 1942. július 21-i keltezésű 5135 sz. alatt felhívása volt a csendőrörs felé. A gyanúsított Glatter Mór 1900. június 16-án született Ásvány községben, izraelita vallású, nőtlen, siklósbodonyi lakos, foglalkozása szerint molnársegéd volt, akinek műveltségi foka az írás és olvasás készsége volt. Glatter vagyontalan volt, katonai szolgálatot nem teljesített, és a Sárospataki Királyi Járásbíróság 1937-ben sikkasztás miatt 4 havi fogházra ítélte. Glatter tagadta, hogy Patalin Józsefnével házasságon kívül nemileg közösült volna vagy azzal szerelmi viszonyt folytatna. Előadta, hogy Patalin Józsefné szokta a ruháit kimosni, és ezért kereste fel ôt rendszeresen. Beismerte, hogy többször megfordult az asszony lakásán, és utoljára 1942. július 2. és 4. között tartózkodott ott. Beismerte azt is, hogy az éjszakákat is ott töltötte, de védelmére előadta, hogy Patalinnét már régebb idő óta ismeri, mert annak férje nála, mint gépész volt alkalmazásban, amikor még bérelt malma volt. 
A csendőrség a nőt és férjét tanúként hallgatta ki. Patalin Józsefné Tóth Rozália 1901. július 4én született. Római katolikus vallású volt. Férjétől különválva Pécs-Nagyárpádon élt, ahol saját háztartásában dolgozott. Tagadta, hogy viszonyt folytatott volna a gyanúsítttal, aki hozzá csak mosatni járt. Patalin József, aki 16 évvel volt idősebb az asszonynál, a gyanúsított alkalmazásában 1938-tól 1941 januárjáig állt. Mivel „Glatter malombérleti szerződése Okorág községben lejárt, ezért onnan Siklósbodony községbe mentek, abol ö Runyai János malomtulajdonos malmát kibérelte. Azért bérelte ö ki a malmot, mert gyanúsitottal már elóróleg abban állapodtak. meg, hogy tekintve, hogy gyanúsitott ssidó, a malmot nem bérelhette ki, azonban a jövedelem fele a gyanúsitotté lett. Gyanuisitott pedig mint munkás szerepelt a malomban. $V$ eszelkedés közte és felesége között 1941 szeptember havában történt, mivel kijelentette, hogy zsidórt nem tartja a bátát. Ekkor ezen kijelentésére felesége, gyanúsitott, Runyai malomtulajdonos és annak felesége reá támadtak, bogy csak ballgasson, itt minden mehet szépen. Az összejövetelek, felesége és gyanúsitott részéröl mindig Runyai malomtulajdnos lakásán voltak, abol sokszor 23-24 óráig együtt volt felesége gyanúsitottal. Felesége neki 1941 október havától neki nem fö̌ött, gyanúsitottnak azonban igen. Elöadta még, hogy (...) több alkalommal

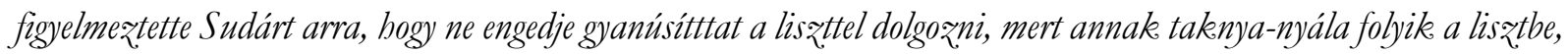
ami igen undoritó. Erre Sudár azt felelte, hogy csak maradjon békében, ne szóljon egy szót sem. Ezen figyelmętetést több alkalommal is megismételte, de Sudár a gyanúsitottat a liszttel való foglalkozástól nem tiltotta el. Gyanúsitott és felesége viszonya úgy kędett elótte gyanússá válni, hogy felesége az ô szavát sem hagyta jóvá, míg gyanúsitott akármit is mondott, annak mindig igazat adott. 1941 szeptember havában kereste a szerzódést, amit a malombérlésról csináltak, azonban azt sebl sem találta, mert felesége és gyanúsitott azt eltették. Feleségét ekekor kérdôre is vonta, hogy hol van a szerzódés, mire az ąt felelte, hogy semmi közös hozzá, akárbol is van. Mivel látta, hogy mindenki ellene van, ezért a helyét 1942. január 1-jén otthagyta és bucsui lakására távozott. Elóadta továbbá, bogy azon idô alatt, míg Siklósbodonyban tartózkodott, a zsidóra a felesége szokott mosni. ${ }^{\prime 56}$

Sudás István, akit szintén tanúként hallgattak ki, társtulajdonosa volt a bérelt malomnak. Előadta, hogy társa, Runyai a molnár szakmához nem ért, és ezért gyanúsított helyette dolgozik ott malommunkásként. Ennek Patalinnével való viszonyáról semmit sem tudott. Runyai János szintén úgy nyilatkozott, hogy nincs tudomása a felek közötti szerelmi viszonyról, illetve előadta, hogy Patalin és a gyanúsított mintegy húsz évig dolgoztak együtt. Bár a csendőrség két további tanút, az izraelita Weisz Simonné Hochvald Margitot és a római katolikus Bajnai Józsefet, Weisz. Simon pécsi marhakereskedő alkalmazottját is kikérdezte, egyikük sem tanúsítta a Glatter és Patalinné közötti alkalmi vagy tartós viszonyt.

A jelentést egy megjegyzéssel zárta a csendőrkerület: „A nyomozás idején a járör gyanúsitottat már nem találta siklósbodonyi lakásában, és az volt a járör gyanúja, hogy nevezett akekor is nevezett nônél tartózkodhatik. Ezért a járór Pécsen Weisz. Simon marbakereskedö lakásán megjelent, és ott az annak alkalmazásában lévö hajcsártól megtudta, hogy gyanúsitott Nagyárpád községben tartózłoodik Patalinnénál. Erröl valószínüleg tudott Weiszné is, de tagadta, hogy tudna róla." A járôr a jelentésben elmondta azt is, hogy a nevezett nő lakásán csak egy ágyat látott, és gyanúsított akkor már harmadik napja ott tartózkodott a ruhamosás ürügye lalatt, de sem kimosott, sem szennyes ruhát nem tudtak felmutatni. Hozzáfüzték azt is, sokal olcsóbb volna, ha a gyanúsított lakóhelyén mosatna magára, nem Nagyárpádban Patalinnénál, illetve hogy a névtelen levél írójának kilétét a járőrnek nem sikerült

\footnotetext{
${ }^{56}$ MNL BML VII/2b 3046/1942, 161. sz. feljelentés, 1942. július 21.
} 
megállapítania. ${ }^{57}$ A pécsi királyi ügyészség a nyomozati iratok alapján 1942. július 24-én emelt vádat az ekkor 42 éves Glatter Mór ellen. ${ }^{58}$

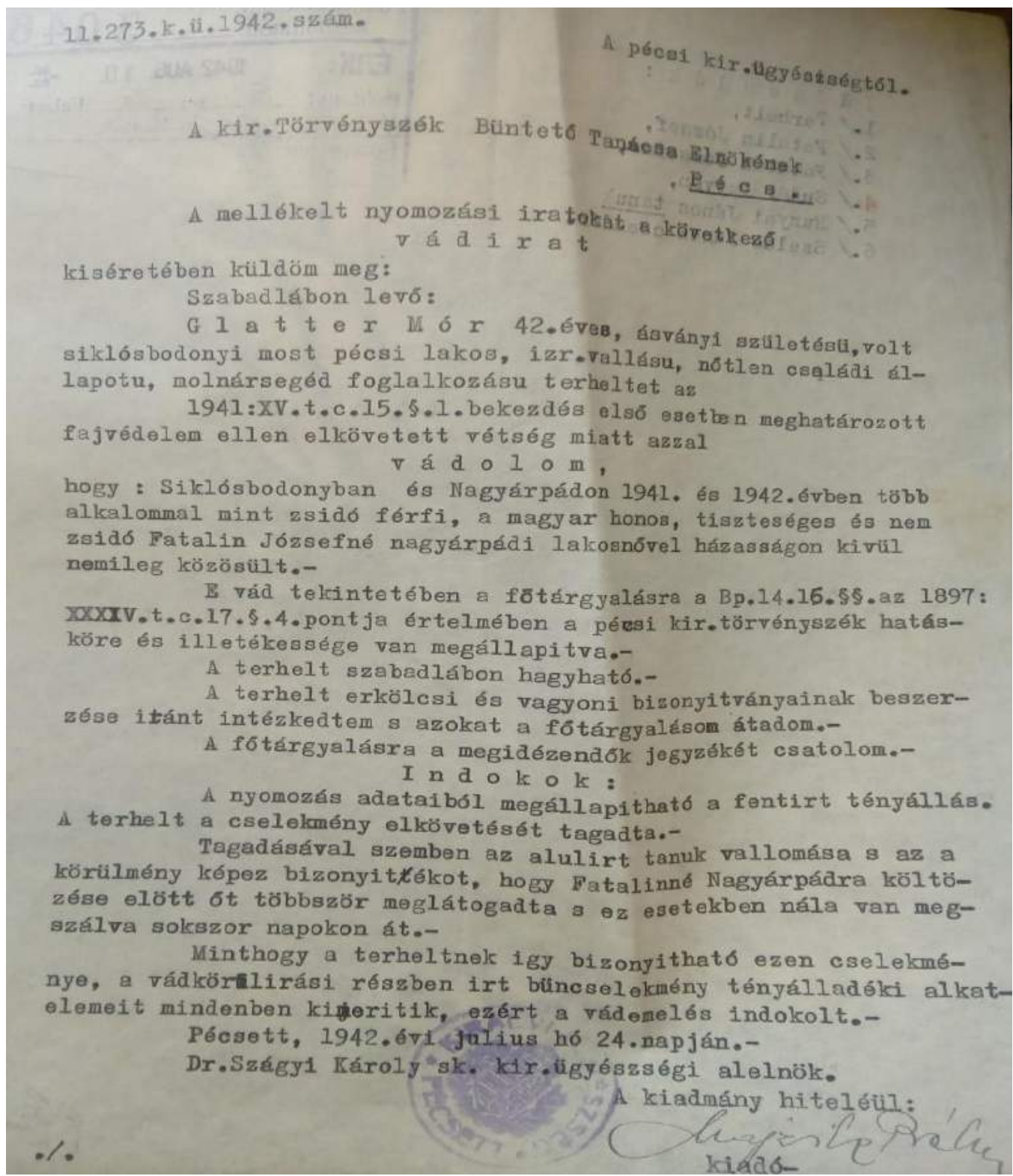

7. ábra: A Glatter Mór elleni 11.273 sz. vádirat, 1942. július 24. MNL BML VII/2b 3046/1942

Az ügyben a Pécsi Királyi Törvényszék 1942. október 21-én hozott ítéletet. Glatter Mórt a fajvédelem ellen elkövetett vétség vádja alól a Bp. 326. \2. pontjának első esete alapján felmentették. Az indokok között szerepelt, hogy a vádlott nem ismerte el bűnösségét. Előadta, hogy ruhái mosása miatt kereste csak fel a nőt, és hogy legutóbbi látogatásakor, 1942. július 2. és 4. között, bár valóban ott aludt, külön szobában töltötte az éjszakát. Másrészt ,vádlott védekęzése a fötárgyaláson megcáfolást nem nyert, mert a kihallgatott tanúk, nevezetesen Patalin József, Sudár István, Runyai

${ }^{57}$ MNL BML VII/2b 3046/1942, 161. sz. feljelentés, 1942. július 21.

${ }^{58}$ MNL BML VII/2b 3046/1942, 11.273 sz. vádirat, 1942. július 24. 
János és Széles János tanúk egyöntetüen vallották, miszerint nem látták az̨t és nem hallttak arról, hogy vádlott Patalinnéval együtt aludt volna, avagy szerelmi viszonyt folytatott volna. Íly körülmények között a kir. törvényszée nem tartja bebizonyitottnak (...) az ügydöntö körülményt (...).” Az ítéletet Garay Lajos tanácselnök, főtárgyalási elnök, Bu₹ás Árpád tanácselnök és Pongrácz István bíró, az ügy előadója hozta meg. ${ }^{59}$

Az 57 éves pécsi éjjeliőr, Weisz. Ignácz ellen folytatólagosan elkövetett egyrendbeli fajgyalázás vétségének vádjával indult büntetőeljárás. ${ }^{60} \mathrm{~A}$ sértett Bálint Julia római katolikus vallású és nem zsidó származású volt. Az 1942. augusztus 24-én felvett nyomozati jegyzőkönyv szerint a vádlott védekezésül előadta, hogy évek óta asztmában és vérbajban szenved, már nem munkabíró, ezért gyámolítóra volt szüksége. Három éve élettársa a sértett, aki szintén beteges. Céljuk az volt, hogy egymáson szükség esetén segíteni tudjanak. A III. zsidótörvény hatályba lépése óta egymással nem közüsültek, de egyébként is öreg emberek már, nemi vágyak nélkül. Ố éjjeliôrként, a nő pedig bejárónőként keresi kenyerét, azaz váltják egymást az ágyon, alig találkoznak az eltérő beosztás miatt. ${ }^{61}$ Felmentő ítélet az ügyben a Bp. 326. \2. pont 1. esete alapján, bizonyítottság hiánya miatt született 1942. november 27 -én. ${ }^{62}$

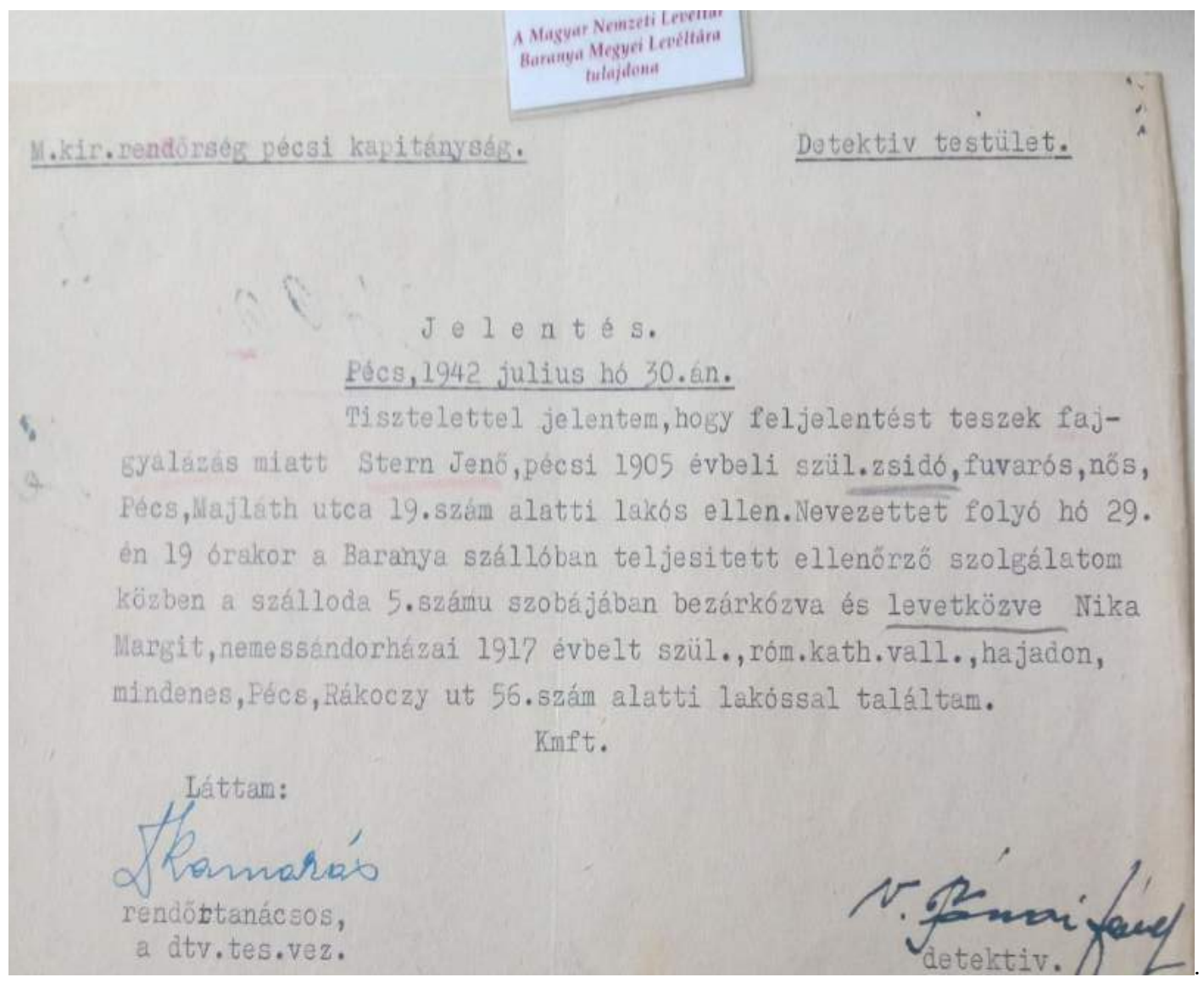

8. ábra: Fónai Jórsef detektív jelentése. MNL BML VII/2b 3458/1942 sz.

\footnotetext{
${ }^{59}$ MNL BML VII/2b 3046/1942/3. sz. ítélet, 1942. október 21.

${ }^{60}$ MNL BML VII/2b 3229/1942/12733 sz. vádirat, 1942. szeptember 13.

${ }^{61}$ MNL BML VII/2b 3229/1942/3 sz. jegyzőkönyv.

${ }^{62}$ MNL BML VII/2b 3229/1942/ 5 sz. ítélet.
} 
A 37 éves, nős zsidó fuvarost, Stern Jenôt 1942. július 30-án jelentették fel, miután Fónai József detektív - valószínűleg a szobaasszony értesítését követően - a Baranya Szállóban Nika Margit római katolikus hajadonnal egy zárt szobában levetkőzve találta anélkül, hogy tanúja lett volna magának a nemi kapcsolatnak. ${ }^{63} \mathrm{~A}$ sértett vallomása szerint a vádlott rendszeresen szállított fát a nő munkaadójának, ezért ismerték egymást. A vádlott nemi közösülésre vonatkozó ajánlatát egy öl fa ellenében fogadta el. ${ }^{64} \mathrm{Az}$ 1942. november 16-án felvett tárgyalási jegyzőkönyv szerint a vádlottat munkaszolgálatra hívták be, ezért a bíróság előtt nem tudott megjelenni. ${ }^{65}$ Az ügyben 1944. március 6-án bizonyítottság hiányában felmentô ítélet született. ${ }^{66}$

A Pécsi Királyi Törvényszék előtt 1942-ben folyamatba tett ügyek között végezetül a 45 éves, özvegy, munkanélküli, volt fatelepi munkás, Fischer Ernő ellen egyrendbeli, folytatólagosan elkövetett fajgyalázás vétsége és az 1937. évi X. tc. 2. \-ba ütköző valótlan hír terjesztése vétsége miatt indított büntetőeljárást kell megemlíteni. A vádirat szerint Fischer egy keresztény nővel meg nem határozható alkalommal nemileg érintkezett, illetve azt a kijelentést tette, hogy a háborút feltétlenül Magyarország ellenségei fogják megnyerni. ${ }^{67}$ Az 1942. június 20-i jelentésben beszámoltak arról, hogy a vádlottal vadházasságban élő Bosnyák Margit „már saját rubáit, értéktárgyait stb. adogatja el, csakhogy a zsidót tartani tudja. (...) rokonai kérték, hogy hagyjon föl a ssidóval, de nevezett nö kijelentette, hogy nem hagyhatja el, mert Fischerböl idôvel még hires ember lehet. A ssidó valamint a keresztény nö angolbarát érzelmeiket hangoztatják. Bosnyák. Margit teljesen a zsidó befolyása alá került, mostmár nem bír szabadulni". ${ }^{68}$ Egy újabb, 1942. november 6-i nyomozati jelentés szerint a feljelentő, Hegedüs György határozott tudomással bírt arról, hogy a Fischer és Bosnyák. Margit a fajvédelmi törvény hatályba lépése után is folytatta az ekkor már 10 éve tartó szerelemi viszonyát. A valószínúleg visszautasított Hegedüs figyelmeztette a nőt, majd mivel az továbbra is fenntartotta a viszonyát Fischerrel, jelentést tett. ${ }^{69}$ A bíróság az eljárást - mivel a tárgyalás alkalmával a közvádló bizonyítottság hiányában a vádat ejtette, pótmagánvádnak pedig helye nem volt - 1943. január 23-án megszüntette. ${ }^{70}$

A Pécsi Királyi Ügyészség és a Pécsi Királyi Törvényszék enyhe hozzáállását a fajgyalázási perekben a bontóperek kapcsán tett észrevétellel lehet magyarázni. A Ht. hatályba lépését követő első évek után hazánban egységesen érvényesült az a szemléletmód, hogy a házasságtörés bontóoka esetén (Ht. 76. \$) a teljes bizonyítottsághoz tetten érést vártak el. Ha a tanúvallomások alapján nem volt megállapítható, hogy a nemi érintkezést a tanúk konkrétan látták, házasságtörés helyett erkölcstelen élet megátalkodott folytatása (Ht. 80. \a.) alapján bontották fel a házasságot. A bizonyítottságnak ezt a fokát vártak el a fajgyalázási perekben is.

Ezzel a bírói hozzáállással szemben a nyomozati jelentések szóhasználata a zsidó származású vagy vallású terhelteket illetően rendkívül negatív és sértő volt, melynek azonban jogi jelentősége nem volt. Figyelemre méltó az is, hogy a feltételezett fajgyalázási esetek feljelentés útján jutottak a nyomozóhatóság tudomására, ami ismét sokkal inkább a társadalmi mentalitásra, mint a jogászi szakmunka jellegére utal.

\footnotetext{
${ }^{63}$ MNL BML VII/2b 3458/1942 sz., feljelentés, 1942. július 30.

${ }^{64}$ MNL BML VII/2b 3458/1942 sz.

${ }^{65}$ MNL BML VII/2b 3458/1942/4 sz. jegyzőkönyv.

${ }^{66}$ MNL BML VII/2b 3458/1942/14 sz. ítélet.

${ }^{67}$ MNL BML VII/2b 4837/1942/17625 sz. vádirat.

${ }^{68}$ MNL BML VII/2b 4837/1942/318 sz. jelentés.

${ }^{69}$ MNL BML VII/2b 4837/1942/6385 sz. jelentés.

${ }^{70}$ MNL BML VII/2b 4837/1942/4 sz. végzés.
} 


\subsection{A jogkorlátozó, illetve jogfosztó normák közvetett hatása más családjogi vonatkozású ügytípusoknál}

Létezhet olyan korszak, amikor a törvénytelen származású gyermek számára kedvezőtlen, ha természetes apja elismeri, hogy tőle származik? A vizsgált levéltári források alapján a válasz sajnos igen.

Kornbäuser Antal pécsi lakos apai elismerő nyilatkozat hatálytalanítása iránt indított pert anyja, özv. Kornhäuser Antalné pécsi lakos, valamint apja, Kornbäuser Antal (írói álnevén Poór Antal) törvényes örökösei ellen 1942. április 3-án. Keresetében előadta, hogy - ha hihetünk neki szándéka nem a fajvédelmi törvény kijátszása volt: 1903. szeptember 24-én született, míg édesanyja és nevelőapja házasságkötésének, illetve az atyai elismerő nyilatkozatnak az időpontja mintegy kilenc évvel későbbi. Anyja vallását követve születését követően a református egyház keresztelte meg. Anyja a kilenc évvel későbbi házasságkötés előtt átlépett a római katolikus egyházba, és így zsidó származású férjével egyvallású lett. (A Feigenbaum Teréz és Kornhäuser József gyermekeként született néhai Kornbäuser Antalt római katolikusnak keresztelték.) Ezért ő sem az 1939. évi IV. tc. \2. bek. 1. pontja és 3. bek. b, pontja, sem az 1941. évi XV. tc. 9. \3. bek. alapján nem minősült zsidónak - érvelt a kerestlevélben. A precízen megfogalmazott iratban kifejtette, hogy a jogi kérdést elsősorban abban látja, hogy a törvényesített gyermek és az anya jogosult-e az apasági vélelem megtámadására.

A korszak magánjogi joggyakorlatában az ún. utóházassággal történő törvényesítés ${ }^{71}$ szabályai már kikristályozódtak. Miután az 1868. évi LIV. tc. hatályba lépésével a születés törvényességének a kérdésével összefüggő perek is (22. §) állami bíróságok hatáskörébe kerültek, a bírói joggyakorlatban a századforduló éveire rögzültek a kánonjogi eredetú jogintézmény szabályai. Az utóházassággal való törvényesítés akkor következett be, ha a nemző szülók természetes gyermekük születése után egymással házasságra léptek, föltéve, hogy a nemző szülők között a gyermek nemzése idejében olyan házassági akadály nem volt, amely alól nem lehetett felmentést adni. ${ }^{72}$ A törvényesítéshez az érintettek beleegyezését nem kívánták meg, és nem volt szükség arra sem, hogy az anya férje a gyermeket kifejezetten elismerje. Elégségesnek tartották annak bebizonyulását, hogy a gyermek nemzése idején az anyával közösült, melynek elismerése a felekezeti jogokban valamely egyházi hatóság előtti nyilatkozattal történt. A (közösülés tényén túl) a kifejezett atyai elismerő nyilatkozatnak azonban a törvényesítés tekintetében nem volt jelentősége, az abból származó jogok függetlenek voltak a nyilatkozattól. Ennek ellenére az utóházasság megtörténtének a felekezeti születési anyakönyvbe történő bejegyzéséhez megkívánták, hogy a házasságra lépő férfi alakszerű jognyilatkozatot tegyen. Ennek szabályai felekezetenként némi eltérést mutattak.

\footnotetext{
${ }^{71}$ Börcsök Andor az utóházassággal való törvényesítés mellett a királyi leiríttal történő törvényesítést nevezte meg a 19-20. század fordulójának joggyakorlatában, illetve említést tett a pápai törvényesítésről, melynek ekkor magánjogi joghatása hazánkban már nem volt. BÖRCSÖK, Törvényesítés 643.

${ }^{72}$ BÖRCSÖK, Törvényesítés 644.
} 


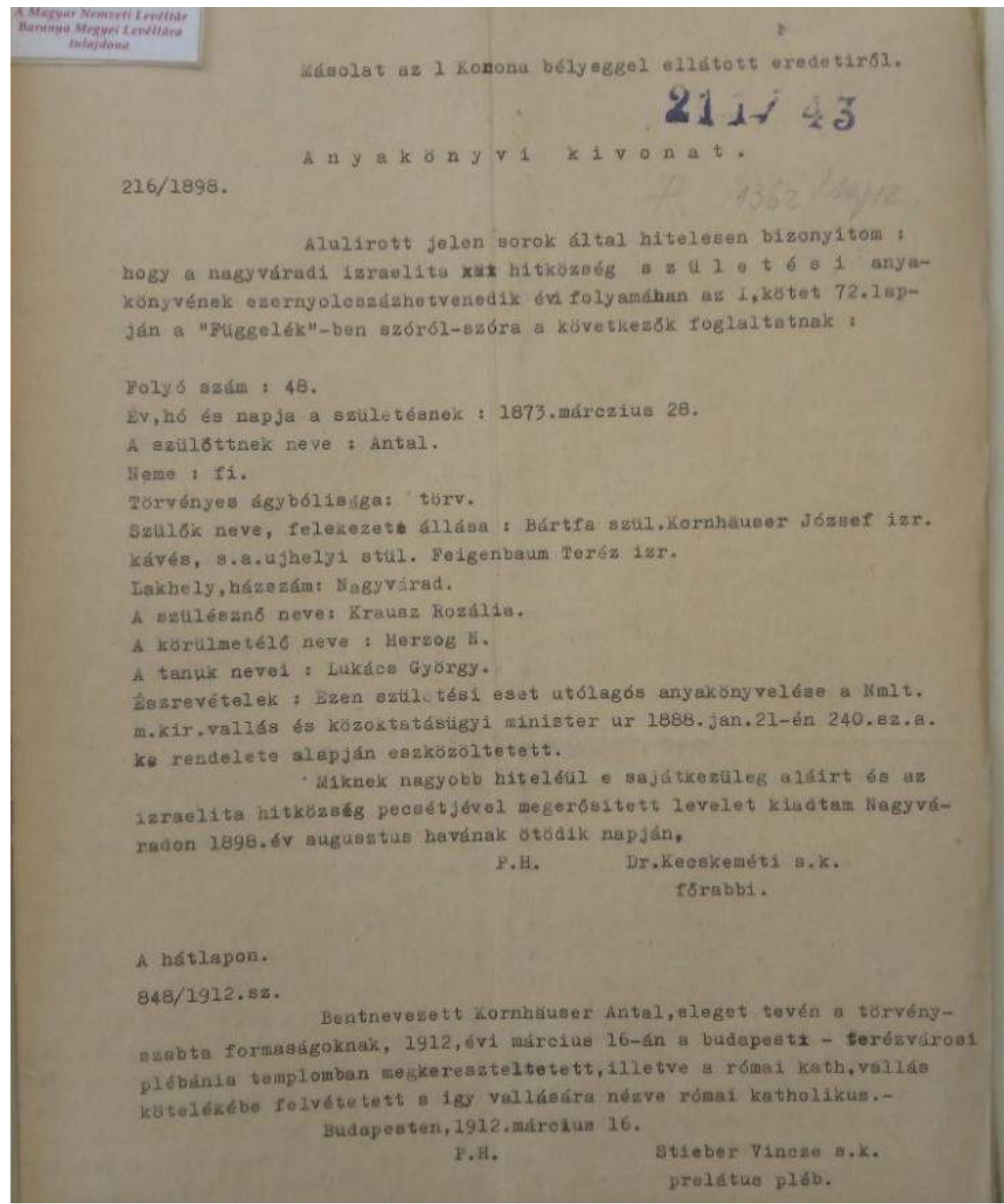

9. ábra: MNL BML VII/2b 1362/1942 számú ügyhöz csatolt születési anyakönyvi kivonat

Az egységesítés a Ht. (1894. évi XXXI. tc.) illetve az állami anyakönyvezésről szóló 1894. évi XXXIII. tc. hatályba lépésével valósult meg. 1895. október 1. után csupán az olyan utólagos házasságkötésnek nem lehetett törvényesítő hatálya, amelyet nem polgári tisztviselő előtt kötöttek. $\mathrm{Az}$ anyakönyvi törvény szerint már nem az utóházassággal való törvényesítést, hanem két ténykörülményt jegyezhettek fel: az apaság elismerését (41. §) és az utóházasság megkötését (43. §). A feljegyzés célja a közhiteles nyilvántartás volt, míg az e tényekből származó joghatásokat a törvény nem szabályozta. A korszak jogirodalma szerint e két ténykörülmény volt az, amelyből „a 
törvényesitésre követkeatetni lehet és kell, ha semmi akadályozó körülmény nem fordul elö. Ennélfogva mindannyiszor, midón valamely hatóság által a fennforgó esetben követendó szabályok a törévnyesitésnek bivatalból való megvizsgálását nem kivánják, a gyermek, akire vonatkozóan az anyakönyvbe a kérdéses ténykörülmények föl vannak jegyezue, mindaddig, míg az ellenkęô" ki nem világlik, törvényesitettnek lesz. tekintendö" "73 Az eljáró hatóság azonban hivatalból nyomozás tárgyává tehette a fenti ténykörülményeket, illetve ellenérdekủ fél kifogása alapján figyelembe vehette azokat a ténykörülményeket is, melyek a törvényesítést kizárják. Ilyen ténykörülményként nevesítette Börcsök Andor a következőket: 1. a gyermeket nem a házasságra lépő fél nemzette, azaz az elismerés nem felelt meg a valóságnak; 2 a szülők között a gyermek nemzésekor olyan házassági akadály állt fenn, mely alól nem volt lehetőség a felmentésre. ${ }^{74}$ A korszak szakirodalma nem tért ki arra a kérdésre, hogy a törvényesített gyermek a jogállását eredményező nyilatkozatot megtámadhatta-e, ami arra enged következetni, hogy a joggyakorlat során ilyen helyzet nem fordult elő.

A fent ismertetett perben a felperes, ifj. Kornbäuser Antal álláspontja szerint az apasági vélelem megtámadása csak a törvényes gyermek esetén ütközik jogszabályi tilalomba, törvénytelen gyermek esetében nem. Másodsorban feltette azt a kérdést is, hogy még az atyai elismerő nyilatkozathoz a vélelmezett fogantatási időben történt nemi érintkezést bizonyítani - a Ht. és az anyakönyvi törvény hatályba lépésétől már - nem kellett, ennek ellenkezőjére van-e lehetőség, azaz a törvényesített gyermek bizonyíthatja-e azt, hogy nem volt ilyen kapcsolat az érintettek között. A felperes úgy vélte, hogy az ehhez való jog a legitimizált személyt korlátlanul megilleti. Ezért bizonyítani kívánta, hogy a fogantatási időben anyja és Kornbäuser Antal között nem volt nemi kapcsolat, és így az apai elismerő nyilatkozat és az utólagos házasságkötés az ô törvényesítését nem eredményezhette. $^{75}$

Az ügyben a Pécsi Királyi Törvényszék 1942. november 13-án hozott ítéletet. A felperes keresetének a bíróság helyt adott, azaz kimondta, hogy „nébai Kornbäuser Antalnak azon nyilatkoz̧ata, amellyel felperest saját nemzéséböl származó gyermekének az I. rendü alperessel 1912 évi junius hó 25. napján megkötött házassága elött elismerte, érvénytelen. Kimond(ta) továbbá ennek folyamányaként, hogy felperes néhai Kornbäuser Antal nemzéséböl nem származ̧hatott, továbbá a most nevezettnek az. I. rendú alperessel kötött házassága nem ,utólagos házasság;, továbbá hogy ezen házasságkötés felperes törvényesitését nem eredményehette", valamint a törvényesítésről szóló anyakönyvi bejegyzést semmissé nyilvánította. Az ítélet indokolása két tanúvallomáson alapult, melyek szerint az édesanya és néhai Kornhäuser Antal a fogantatási idôn kívül ismerte meg egymást, és a természetes atya más. ${ }^{76}$

Ezzel az apai elismerő nyilatkozat hatálytalanítása iránti perrel szemben gyakori ügytípus volt a korábbi évtizedek bírói gyakorlatásban és a vizsgált levéltári anyagban is a gyermek törvényes származásának megtámadása a vélelmezett apa (a féri) által, melyet a periratokban többnyire törvénytelen származás megállapítása iránti pernek neveztek. ${ }^{77}$ Ezek között újdonság a korábbi eljáráshoz képest vagy diszkriminációra utaló jel nem volt. Természtesen - mint minden etnikai vagy vallási csoport esetében - zsidó házastársak között is előfordult ilyen per, melyeket a vélelmezett apa, a férj indított a kiskorú gyermek és törvényes képviselője, rendszerint az anya ellen.

\footnotetext{
73 BÖRCSÖK, Törvényesítés 645.

${ }^{74}$ 60.000/95. BM. sz. rendelet 54., 61. és 62. SS (ún. anyakönyvi utasítás).

${ }^{75}$ MNL BML VII/2b 1362/1942 sz., szám nélküli keresetlevél, 1942. április 30.

${ }^{76}$ MNL BML VII/2b 1362/1942/13 sz. itélet.

${ }^{77}$ Lásd többek között MNL BML II/2b 49/1942 és 577/1942 sz.
} 
A felek vallása vagy származása ezekben az ügyekben rendszerint csak közvetetten derül ki, hiszen jogi jelentősége nem volt. ${ }^{78} \mathrm{~A}$ törvénytelen gyermekek tartásra való jogosultsága ${ }^{79}$ illetve öröklési joga végrendelet hiányában 1946-ig (az 1946. évi XXIX. tc. hatályba lépéséig) nem volt megnyugtatóan rendszeve a magyar magánjogban. E kérdések vizsgálata a baranyai ítélkezési gyakorlatban külön tanulmány tárgyát képezi.

Gyakoriak voltak a Pécsi Királyi Törvényszék előtti perek között az örökbefogadási ügyek. ${ }^{80}$ A kiskorú vagy nagykorú személyek örökbefogadása Magyarországon az 1952. évi IV. tv. hatályba lépéséig szerződéses jogügylet volt, melyhez csupán közjegyzői okiratba foglalásra, illetve utólagos megerősítésre volt szükség. ${ }^{81} 1867$ óta a magyar királyi igazságügyminiszter erősítette meg az ilyen szerződéseket, mely nem jelentett érvényességi feltételt, csupán tanúsította, hogy a szerződés a felek akaratából köttetett, valamint az alaki és anyagi jogszabályoknak megfelelő ügylet volt. A szerződés már a megerősítés előtt is kötötte a feleket, az attól való elállás már nem volt lehetséges. ${ }^{82} \mathrm{~A}$ miniszteri rendeleti formájában kiadott megerősités tartalmazott egy közvetítő hatóságokhoz (kiskorúak esetében az árvaszékhez, nagykorúaknál a törvényszékhez) intézett utasítást is, hogy lássák el a szerződés példányait megerősítő záradékkal, intézkedjenek az örökbefogadás tényének és a névváltozásnak vagy annak a ténynek az anyakönyvbe való bejegyzéséről, hogy az örökbefogadott neve nem változott, a feleket pedig az iratok egyidejû megküldésével értesítsék. ${ }^{83}$ A bírói joggyakorlatban elsősorban az örökbefogadás felbontása iránti ügyek jelentek meg. A szerződés akkor volt felbontható volt, ha az örökbefogadott vagy az örökbefogadó olyan cselekményt követett el, amely miatt a szülő ivadékát vagy az ivadék szülőjét kitagadhatta vagy pedig, ha az örökbefogadott vagy az örökbefogadó az örökbefogadással járó kötelességeit szándékos magaviseletével egyébként oly súlyosan megsértette, emiatt a másik félre nézve az örökbefogadás fenntartása elviselhetetlenné vált. A sértett fél az örökbefogadási szerződés megtámadására vonatkozó szabályoknak megfelelően keresettel kérhette az örökbefogadás bírói felbontását, illetve az örökbefogadási szerződés hatálytalanítását, amennyiben az örökbefogadó és az örökbefogadott is életben volt és a vétkes cselekményt az örökbefogadó nem bocsátotta meg.

Újdonságként a jogfosztás éveiben az örökbefogadási szerződésekben két elem jelent meg: egyrészt a szerződéskötő felek kijelentése arról, hogy nem zsidók, ${ }^{84}$ másrészt az örökbefogadás tényének bejegyzése a felekezeti anyakönyvbe a keresztlevél csatolásával. ${ }^{85}$ A II. világháború éveiben a magánjogi szakirodalom különösen a nemzetközi örökbefogadással kapcsolatos jogvitákban adott útmutatót a jogalkalmazóknak: az állami, közrendészeti szempontok nem tették „kîiánatossá”, hogy az örökbefogadás „konjukturális magánérdekekeet szolgáljon”, és nem engedték az „iparszerüséget”, azaz hogy az örökbefogadó több külföldi állampolgárt örökbe fogadhasson. A miniszteri megerősítést megtagadták, ha az örökbefogadó külföldi állampolgár volt, kivéve azokat

\footnotetext{
${ }^{78}$ Breitner Nándor felperes estében, akinek az idézés azért nem volt kézbesíthető, mert munkaszolgálatra bevonult. MNL BML VII/2b 4111/1942/2 sz. végzés, 1942. november 10.

79 KRAUSZ, A kiskorú gyermek tartása a házasság fennállása alatt és felbomlása után 1938 és 1945 között Magyarországon 16-32.; KRAUSZ, A kiskorú gyermek tartásának szabályozása a polgári korban 83-100.

${ }^{80}$ Lásd többek között MNL BML VII/2b 463/1942 és 4426/1942 sz.

${ }^{81}$ RÉKASINÉ ADAMKÓ, Az örökbefogadás Magyarországon 1946 előtt 72-93.

82 MESZLÉNY, Magyar magánjog I. 700-701.

${ }^{83}$ MESZLÉNY, Magyar magánjog I. 712.

${ }^{84}$ MNL BML VII/2b 2194/1942 sz.

${ }^{85}$ MNL BML VII/2b 4427/1942 sz.
} 
az eseteket, ha az örökbefogadó állama az igazságügyminiszter intézkedését hatályosnak ismerte el, az örökbefogadó Magyarországon lakó, megállapíthatatlan állampolgárságú személy volt, vagy ha a külföldi örökbefogadó hazájának törvényei szerint illetékes hatóságnál a megerősítést megkísérelte, de az nem volt kieszközölhető amiatt, mert a külföldi hatóság magát a megerősítésre illetéktelennek mondta ki arra hivatkova, hogy az örökbefogadott magyar honos. ${ }^{86}$ Sqászy István szerint a nemzetközi örökbefogadások jelentős része színlelt jogügylet volt, amely csak a magyar állampolgárság megszerzésére irányult. Ezzel magyarázta azt, hogy ha magyar örökbefogadóról és külföldi örökbefogadottról volt szó, az örökbefogadott nem szerzett magyar állampolgárságot, hanem csak a kedvezményes honosítás lehetősége állt fenn. ${ }^{87}$ Nemzetközi örökbefogadással kapcsolatos jogvita a vizsgált levéltári anyagban nem volt.

Ellenben gyakori ügytípusnak bizonyultak az öröklési szerződés hatálytalanítása iránti perek. Mivel az öröklési szerződés rendszerint azt a célt szolgálta, hogy a halála esetére rendelkező idős személyt vagy személyeket (gyakran szülőket) a szerződő fél (gyermek) azok haláláig eltartsa és gondozza, a szerződés hatálytalanítását akkor kérték, ha gondozási kötelezettségét a javadalmazott nem teljesítette. ${ }^{88}$ Hasonló okok vezették a következő per felperesét is, bár nem tartásról és gondozásról, hanem bizonyos fizetési kötelezettségek teljesítésének átvállalásáról volt szó. Ezért Braun Osækár ügye elsősorban nem a típus szempontjából különleges, hanem a köztörténeti háttér és a jogfosztó normák (ebben az esetben az árjásítás) következményeinek a megjelenése miatt: a II. zsidótörvény értelmében a részvénytársasági formában múködő vállalatokat kötelezték arra, hogy az igazgatóságban és az ügyvezetőségben az átállítást fokozatosan hajtsák végre, és a törvényben meghatározott arányszámot 1943. január 1-jéig érjék el. ${ }^{89}$

$\mathrm{Az}$ apa, Braun Osžár részvénytársasági igazgató és törvényes fia, Braun Mátyás háztulajdonos, aki a Rosenberger Júliával kötött házasságból született, 1939. január 30-án kötött örökösödési szerződést. Mindketten Pécs belvárosában éltek: Os₹̨ár a József u. 13. szám alatt, Mátyás a Gr. Benyovszky Móric u. 10. szám alatt.) Nem sokkal később, 1942 nyarán azonban az apa pert indított fia ellen öröklési szerződés érvénytelenné nyilvánítása iránt.

A tárgyalási jegyzőkönyv szerint Kisfaludi Imre pécsi ügyvéd Krisz̧tics Sándor jogászprofesszor ${ }^{90}$ megbízásából 1941 áprilisától tárgyalásokat folytatott Braun Oszłárral az „Agrária részuények megvételéról”, melyben az a meggyőződés vezette, hogy a részvények az alperes tulajdonát képezik. Egy ízben az atyával is folytatott megbeszélést, de ekkor a részvények tulajdonának kérdése nem került el, és számára egyértelmű volt, hogy az atya már elốzetesen is tárgyalt Krisztics professzorral az adásvételről. Az utolsó árajánlatot az ügyvéd Krisztics megbízásából 1941. május 15-én tette, mely szerint 1.813 darab részvényt 55.000 pengőért kívánt megvásárolni, amely 30,3 pengőt jelent részvényenként. Vallomása szerint a felek előtte a tulajdonjog kérdéséről sosem nyilatkoztak. A jegyzőkönyv tartalmazta Braun Osžkár feleségének, Wallenstein Magdának a vallomását is. Eszerint apósa neki azt a kijelentést tette, hogy „mit akar Osžkár, mikor a részuényeket

\footnotetext{
86 SZÁSZY, Magyar nemzetközi magánjog I. 462-464.

${ }^{87}$ SZÁSZY, Magyar nemzetközi magánjog I. 462-464.

${ }^{88}$ Lásd például MNL BML VII/2b 1309/1942 sz.

${ }^{89}$ Lásd hozzá HEGEDÜs, Ôrségváltás 2.

${ }^{90}$ Krisz̧tics Sándor (1890-1966) 1925 és 1949 között volt Pécsett a jogbölcselet és a politika tárgyak professzora. Lásd https://www.arcanum.hu/en/online-kiadvanyok/Lexikonok-magyar-eletrajzi-lexikon-7428D/k-760F2/kriszticssandor-76775/ (2020.01.13.)
} 
is oda ajándékoztam és mindenemet oda adtam”, és emlékezete szerint az örökösödési szerződés megkötése előtt (1939. január 30.) a részvények már férje tulajdonában voltak. Eötvös Jenő nyug. takarékpénztári igazgató vallomása szerint ő felperes atyának, akit tudomása szerint az összes részvények 70-80\%-a illetett, vevőként Karl Gus₹távot ajánlotta, miután Krisz̨tics professzorral nem sikerült megállapodni. A tárgyalások során az volt a feltevése, hogy alperes fiú a felperes atya megbízásából járt el. Emlékezete szerint 1941. május 22-én nyilatkozott előtte felperes úgy, hogy fiának „átadja” az Agrária részvényeket, amennyiben az mentesíti minden más „obligo” alól. Eötvös Jenô vallomása szerint „az. Agrária r. t. jogutódjánál, amely egyéni cég”, alperes csak alkalmazott volt, míg Eötvös cégvezető, a tulajdonos pedig Karl Gusztáv volt. A bíróság tanúként hallgatta ki az 59 éves bonyhádi cipőgyáros Karl Gusztávot is. Az advételi szerződéssel kapcsolatban, melyet 1941. május 20-án kötöttek meg, ő kizárólag alperessel folytatott tárgyalásokat, vele alkudta ki a 45 pengős részvényenkénti vételeárat. A szerződést nem egyszerre írták alá, azon az eladó aláirása már az övé előtt szerepelt, és felperes a vételár előleg illetve hátralék kifizetésekor sem volt jelen. 1941. június 20-án újabb megállapodást kötöttek 971 db Agrária részvény hitelre történő megvásárlásáról alparessel, melynek ellenértékét még annak ellenére sem fizette ki, hogy „a felsáámolásból a részuényeseknek juttatott összeget én már megkaptam” - állította Karl. ${ }^{11}$

Mintegy négy hónappal az újabb adásvételi szerződés után, 1941. szeptember 25-én Hónig Ferenc pécsi ügyvéd felhívást intézett Braun Os₹łárhoz az öröklési szerződést megszüntető új szerződés aláirására. Az atya hálátlanságra hivatkozott, amely fia részérôl annak ellenére történt, hogy „ö mindeköz̧ben fiának ajándékozta az. Agrária részuényeit".92 A megszüntetésrôl szóló szerződéstervezet, melyet 1941 októberére kelteztek, tartalmazta Braun Osækéar kijelentését is, hogy az édesanyja, néhai Rosenberger Júlia hagyatékából rá háramlott félingatlan tulajdonával édesatyjának, Braun Mátyásnak életében rendelkezni nem fog, az ingatlanjutalékot el nem idegeníti és zálogjoggal meg nem terheli. A megszüntető szerződést, illetve annak záradékát azonban nem írták alá és a keltezésből a nap is hiányzik. ${ }^{93}$ A per anyagához csatolták Braun Mátyás és Rosenberger Júlia közös végrendeletének másolatát is, melynek jelentősége az ügyben az volt, hogy Braun Mátyás nyilatkozata szerint minden ingó és igatlan vagyonát házasságuk fennállása alatt szerezte, és ezért azok fele részben közszerzemény címén felesége tulajdonát képezik. ${ }^{94}$

A per 1942. június 10-én a peres felek egyezségével ért véget, melyet a Pécsi Királyi Törvényszéknek az eljárást megszüntető végzéséhez csatoltak. ${ }^{5} \mathrm{Az}$ ügy lényege nem a családi jogvitában (az öröklési szerződésben megállapított fizetési kötelezettségek teljesítésében vagy nem teljesítésében) áll, hanem abban, hogy a periratok alapján rekonstruálható a pécsi Agrária Gyáripari és Kereskedelmi Rt. árjásításának története: az 1942. évi statisztikai adatok szerint az „Agrária keményitő dextringyár és kereskedelmi vállalat”, amely a korszak antiszemita szakirodalma szerint „„sidó" cég volt, ${ }^{96}$ a törvényes határidőn belül ún. „egyéni, nem zsidó tulajdonú céggé" vált, ${ }^{97}$

\footnotetext{
${ }^{91}$ MNL BML VII/2b 170/1942/8 sz. tárgyalási jegyzőkönyv, 1942.június 5.

${ }^{2}$ MNL BML VII/2b 170/1942 sz., szám nélküli ügyvédi felhívás, 1941. szeptember 25.

${ }^{93}$ MNL BML VII/2b 170/1942 sz., szám, aláírás és a nap megjelölése nélküli szerződéstervezet.

${ }^{94}$ MNL BML VII/2b 170/1942 sz., másolat az 1934. szeptember 30-án közjegyzői okiratba foglalt közös végrendeletről.

${ }_{95}$ MNL BML VII/2b 170/1942/9 sz. tárgyalási jegyzőkönyv, 1942.június 10.

${ }^{96}$ HEGEDÜs, Örségváltás 337.

${ }_{97}$ T. MÉREY, Pécs gyáriparának legfontosabb adatai egy 1942-ben készült felmérés tükrében 125-148.
} 
miközben Braun Mátyás, a helyi hitközség elöljáróságának tagja és apja mintegy két év múlva a népirtás áldozatává vált. ${ }^{98}$

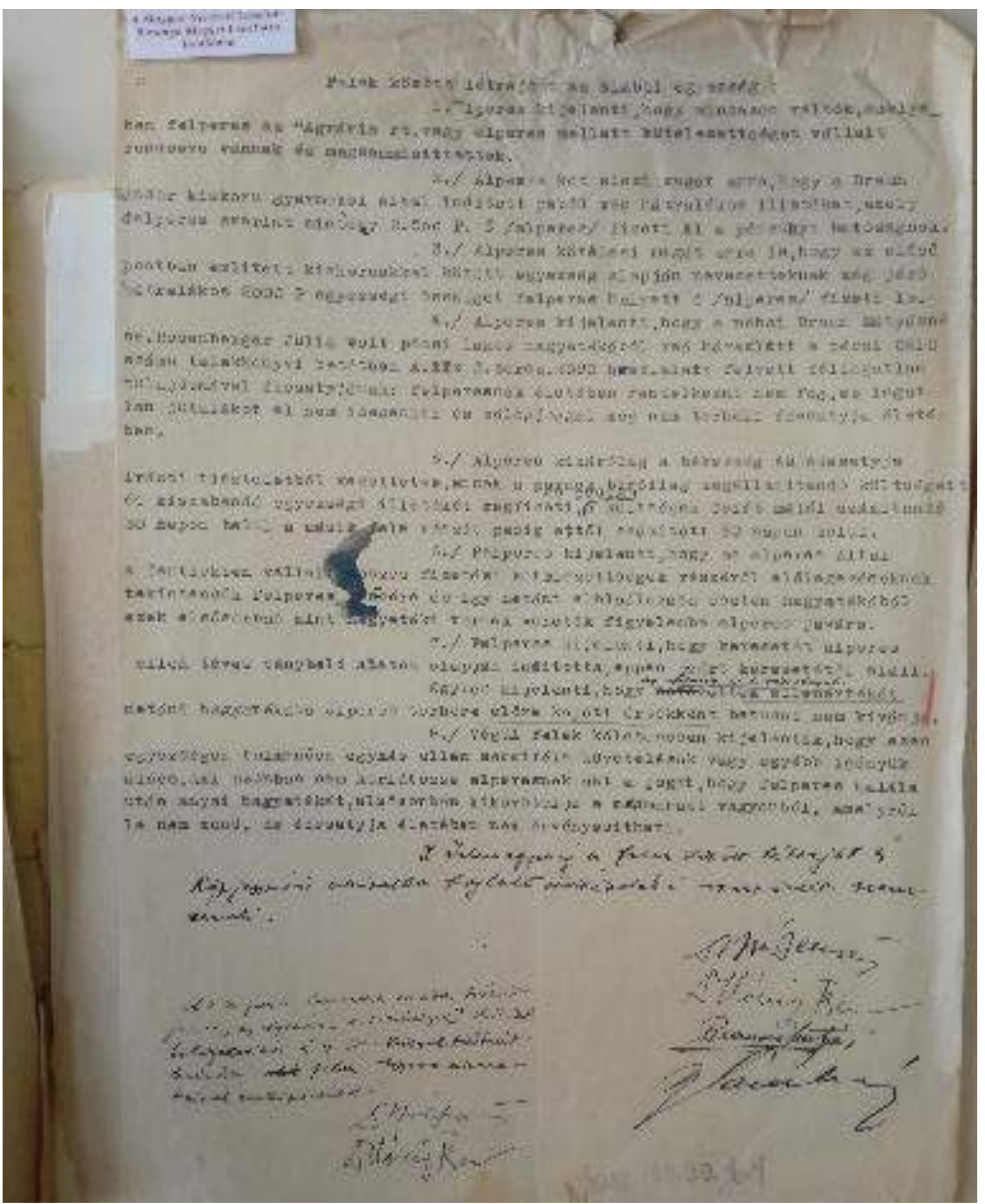

10. ábra: MNL BML VII/2b 170/1942 sz., egyezség, 1942. június 10.

98 A tanulmány szerzője köszönetet mond Schweitz̧er Gábornak a hitközségi iratokon alapuló szóbeli közlésért. 


\section{Következtetések}

A családjogi vontkozású ügyekben a III. zsidótörvény rendelkezéseinek nyilvánvaló szembenállása a „törvény feletti” természetjoggal a vizsgált levéltári anyag alapján csak részben jelent meg. Egyrészt a vizsgált levéltári anyagban egyetlen zsidó-nem zsidó vegyesházasság miatt, vagy annál történt közremúködés miatt indított büntetôper sem volt.

Másrészt a házasság megtámadása kivételes ügytípus volt: 1942-ben a Pécsi Királyi Törvényszék előtt folyamatba tett öt megtámadási per alapján megállapítható, hogy a keresetben az azt benyújtó házastárs a házasság érvénytelenné nyilvánítása mellett minden esetben másodlagosan a házasság felbontását is kérte, amit valószínűleg a megtámadási okok bizonyításának nehézségeivel magyarázhatunk; a házastársak legalább egyike az említett öt megtámadási per közül csak kettôben volt a III. zsidótörvény értelmében zsidó, és származásuknak az ügy érdeme tekintetében nem volt jogi jelentősége egyik perben sem; a vizsgált anyagban nem volt olyan per, melyben a törvény 1 . \$ban meghatározott betegség vonatkozásában szándékos megtévesztésre hivatkoztak volna; míg a házastársnak a házasságkötés időpontjában fennálló, a másik fél gyógyíthatatlan emebetegségre vonatkozó tévedése csak egy esetben szerepelt megtámadási okként a keresetlevélben.

Harmadrészt a törvény bontójogi vonatkozású rendelkezése nem a diszkrimináló normák közé tartozott, hanem csupán a Ht. egy elvét erősítette meg a joggyakorlat ingadozására hivatkozva. A bontójog tekintetében a zsidó származású vagy vallású peres felek alacsony száma, amely szembeötlő a korábbi évtizedekhez képest, valószínúleg a háborús körülményekkel, a férfiak munkaszolgálatra való kötelezésével magyarázható, ami az eljárás felfüggesztéséhez vagy a kereset visszavonásához vezetett. A bontókeresetek - ahogy ez nem zsidó felek esetében is legtöbbször így volt - a Ht. 80. \-án vagy 77. \-án alapultak.

Negyedrészt „a zsidó szellem uralmának” visszaszítására irányuló fajvédelmi rendelkezések alkalmazásával kapcsolatban megállapítható, hogy a baranyai joggyakorlatban kevés, mindösszesen öt 1942-ben folyamatba tett fajgyalázási per volt, melyek két esetben az eljárás megszüntetésével, három esetben felmentő ítélettel végződtek. A Pécsi Királyi Ügyészség és a Pécsi Királyi Törvényszék enyhe hozzáállása nem az ügyészek és jogászok esetleges személyes értékítéletével, hanem a klasszikus polgári jogelvelelvek alkalmazásával magyarázható: a fajgyalázási perekben kétséget kizáróan bizonyítottnak a nemi érintkezés megtörténtét akkor tekintették, ha azt a tanúk konkrétan észleték, egyéb esetben azt a terhelt terhére nem értékelték. Míg társadalmi mentalitás tekintetében feltűnő, hogy a nyomozati jelentések szóhasználata a zsidó származású vagy vallású terhelteket illetően rendkívül negatív és sértő volt, illetve a feltételezett fajgyalázási esetek feljelentés útján jutottak a nyomozóhatóság tudomására, a jogászi szakmunka jellegét tekintve megállapítható, hogy ott, ahol a pozitív jog a klasszikus polgári jogelveket nem írta felül, a jogászok megmaradtak az igazságosság szolgálatában. Ahol azonban a torzulás bekövetkezett, a pozitív norma merev alkalmazói voltak.

Ötödrészt a tág értelemben vett családjogi vonatkozású ügyek jelentős részénél a magánjogi jogkorlátozás, illetve jogfosztás következményei közvetetten jelentek meg. Az örökbefogadási szerződésekben a kötelező záradék a felek nem zsidó voltáról a rasszista jogalkotás kijátszásának megakadályozását szolgálta, míg az apasági vélelemmel szembeni bizonyítási lehetôségnek a törvényesített gyermek részéről önmagában semmi köze nem volt a jogfosztáshoz: az ügy 
hátterében húzódott csak meg az a szándék, hogy ilyen módon az őt elismerő zsidó atyjától (és ennek következményeitől) megszabaduljon a már nagykorú gyermek. Végezetül a fent ismertetett öröklési szerződés hatálytalanítása iránti per jelentôsége nem magában a szerződéskötő felek (apa és fia) közötti jogi konfliktusban, a hálátlanság bizonyításában állt, hanem a családi vita hátterében meghúzódó történetben, a periratok segítségével az apa többségi tulajdonában álló cég árjásításának dokumentálásában.

S hogy a jogalkalmazó azt a normát, amit a konkrét ügyben alkalmaznia kellett, „elviselhetetlenül igasságtalannak” látta-e? Ennek nyomát a periratokban természetesen nem lehet fellelni. Mindenesetre a jogrendszer torzulásának a jellege, a „fekete” és a „fehér” keveredése (a polgári kori jogelvek jelentős részének fennmaradása a társadalom egy részének teljes jogfosztása mellett, a családvédelmi jellegűnek tekintett intézkedések cukormáza, a bírói gyakorlat egységesítésére és stabilizálására irányuló jogállami karakterűnek tekintett rendelkezések, a dogmatikai precizitás igénye a magánjogtudományban) hozzájárulhattak ahhoz, hogy a lelkiismeretét alvásra ösztönözze az, akinek ez a láthatatlan része nem volt halott.

\section{Felhasznált források és irodalom}

70651/1941. I. M. rendelet a házassági jogról szóló 1894: XXXI. t. c. kiegészítéséről és módosításáról, valamint [az] ezzel kapcsolatban szükséges fajvédelmi rendelkezésekről szóló 1941: XV. t. c. 9. és 14-16 \$S-nak hatálybalépéséről. In: NAGY Sándor: A fajvédelem útvesztőjében. Bírói gyakorlat „fajgyalázási“ perekben (1942-1944). Fons 2015/4. sz. 487-532.

Az 1941. évi XV. tc. indokolása https:// net.jogtar.hu/ezer-ev-torveny?docid=94100015.TVI\&searchUrl=/ezer-evtorvenyei\%3Fpagenum\%3D51.

ALFÖLDY Dezső - SzENTMIKLósI István: A házassági per kézikönyve. A legújabb jogszabályokkal és a bírói gyakorlattal kiegészített III. kiadás. Budapest 1942

BÖrCsÖK Andor: Törvényesítés. MÁRKus Dezső (szerk.): Magyar jogi lexikon VI. Budapest 1907, 642-649.

CSÁSzÁR Kinga: A kéjelgésügy szabályozása a dualizmus-kori Magyarországon, különös tekintettel Somogyra. Jura 2012/1. sz. 15-28.

FABINYI Tihamér: A polgári perrendtartás törvénye és joggyakorlata II. Budapest 1931

GÁL Dezső - NYÁRÁDY László: Az örökbefogadás, különös tekintettel a gyakorlati eljárásra. Budapest 1941

HEGEDÜs István: Örségváltás. Budapest 1941 http://mtdaportal.extra.hu/books/hegedus_istvan_orsegvaltas.PDF (2020.01.13.)

HERGER Csabáné: Az igazságosság és a jogtalanság határai a magyar magánjogban (1920-1944). Jura 2019/1. sz. 94 103.

HeRger Csabáné: Tradition und Modernisierung in der Geschichte der Zivilehe in Ungarn. In: THIER, Andreas PFEIFER, Guido - GRZIMEK, Philipp (szerk.): Kontinuitäten und Zäsuren in der Europäischen Rechtsgeschichte. Frankfurt a.M. 1999, 275-282.

HERGER Csabáné: A nővételtől az állami anyakönyvvezetőig. A magyar házassági köteléki jog és az európai modellek. Budapest - Pécs 2006

HERGER Csabáné: A házassági kötelék védelmét szolgáló eszközök az 1911. évi I. tc-ben különös tekintettel a békéltetésre. In: HomOKI-NAGY, Mária (szerk.): A polgári peres eljárás történeti fejlődése Magyarországon. Szeged 2013, 71-94.

JOSEFOVITS László: „Fajgyalázás”. Az 1941: XV. t.-c. 15. \-ának büntetőbírósági joggyakorlata. Budapest 1944

KARÁDY Viktor: Asszimiláció és társadalmi krizis. A magyar zsidó társadalomtörténet konjunkturális vizsgálatához. In: KARÁDY Viktor (szerk.): Zsidóság, polgárosodás, asszimiláció. Budapest 1997

KARÁDY Viktor: A vegyesházasságok Budapesten 1950 előtt. Néhány kutatási eredményről. Múlt és jövö 1993/3. sz. 81-88. http://www.multesjovo.hu/hu/aitdownloadablefiles/download/aitfile/aitfile_id/1294/ (2019. 12. 12.) 
KRAUSz Bernadett: A kiskorú gyermek tartása a házasság fennállása alatt és felbontása után 1938 és 1945 között Magyarországon. Díké 2018/2. sz. 16-32. https://journals.lib.pte.hu/index.php/dike/article/view/144/95 (2020. 01. 13.)

KRAUSz Bernadett: A kiskorú gyermek tartásának szabályozása a polgári korban Magyarországon a hatályos szabályozás tükrében. Díké 2019/1. sz. 83-100. https://journals.lib.pte.hu/index.php/dike/article/view/958/875 (2020. 01. 13.)

LEHOTAY Veronika: Szabadságmegvonó intézkedések a Horthy-korszakban, különös tekintettel a zsidótörvényekre. PhD értekezés. Miskolc 2012

LEHOTAY Veronika: A Miskolci Királyi Ügyészség tevékenysége 1938 és 1944 között. Díké 2018/1. sz. 7-19.

LusICZA Géza: A házassági jogról szóló 1894: XXXI. törvénycikk kiegészítéséről és módosításáról valamint az ezzel kapcsolatban szükséges fajvédelmi rendelkezésekről: 1941: XV. törvénycikk. Budapest 1941

MESZLÉNY Artúr: Magyar Magánjog I. Budapest 1931

MOLNÁR Oszkár: Házasságkötés Budapesten. Tájékoztató a házasságkötéshez szükséges és a házasulók által beszerzendő összes okiratokról. Budapest 1941

MONORI Gábor: Krisztics Sándor (1890-1966). In: KAJTÁR István (szerk.): Pécsi jogászprofesszorok emlékezete (1923-2008). Antológia. Pécs 2008, 93-99.

RADBRUCH, Gustav - HASSEMER, Winfried: Gesetzliches Unrecht und übergesetzliches Recht. Juristische Zeitgeschichte. Kleine Reihe 4, Klassische Texte. Baden-Baden 2002

RADOCSAY, László von: Die Rechtserneuerung in Ungarn. Schriften der Akademie für Deutsches Recht: Gruppe Recht des Auslands Nr. 1. München - Berlin 1942, 1-39.

RÉKASINÉ ADAMKÓ Adrienn: Az örökbefogadás Magyarországon 1946 előtt és az örökbefogadás gyakorlata Baranyában. Díké 2018/1. sz. 72-93. https://journals.lib.pte.hu/index.php/dike/article/view/108/69 (2019. 10. 24.)

SÁRFFY Zoltán: A házassági törvény novellája. In: Ünnepi dolgozatok Dr. Szladits Károly egyetemi tanár 70. születésnapjára. Budapest 1941, 69-77.

STEIN Artúr: A zsidók érvényes házasságának alaki kellékei. Budapest 1941

SZÁsZY István: Magyar nemzetközi magánjog. In: SZLADITS Károly (szerk.): Magyar Magánjog I. Budapest 1941, 374 476.

T. MÉREY Klára: Pécs gyáriparának legfontosabb adatai egy 1942-ben készült felmérés tükrében. In: A Janus Pannonius Múzeum Évkönyve. Pécs 2003

WEISS Emilia: Vétkesség - feldúltság és a házasfelek közös megegyezése a múlt és a ma magyar házassági bontójogában. Jogtudományi Közlöny 1981/11. sz. 909-919. 